\title{
$\mu$ - and $\kappa$-Opioid Receptors Selectively Reduce the Same Transient Components of High-Threshold Calcium Current in Rat Dorsal Root Ganglion Sensory Neurons
}

\author{
Hylan C. Moises, ${ }^{1}$ Konstantin I. Rusin, ${ }^{1}$ and Robert L. Macdonald ${ }^{1,2}$ \\ Departments of 'Physiology and ${ }^{2}$ Neurology, The University of Michigan, Ann Arbor, Michigan 48109-0622
}

\begin{abstract}
Whole-cell patch-clamp recordings were used to examine the regulation of voltage-dependent calcium channels by $\mu$-and $k$-opioid receptors in acutely isolated rat dorsal root ganglion (DRG) sensory neurons. Agonists selective for either $\mu$ - (Tyr-Pro-NMePhe-D-Pro-NH ${ }_{2}$, PLO 17) or $k$-opioid receptors (dynorphin A, U69,593) inhibited high-threshold calcium currents in a reversible and naloxone-sensitive manner, whereas administration of D-Pen ${ }^{2,5}$-enkephalin, a $\delta$-selective agonist, was without effect. However, none of the opioids reduced low-threshold T-type currents. The inhibitory effects of PLO17 were blocked by the irreversible $\mu$-opioid antagonist $\beta$-funaltrexamine but not the $\kappa$-opioid antagonist nor-binaltorphimine, while responses to $\alpha$-opioid agonists showed the opposite pattern of antagonist sensitivity. In addition, many cells responded to both PLO17 and dynorphin A (or U69,593), and in these neurons the inhibitory response to one agonist was occluded when tested in the presence of the other. These data suggest that $\mu$ - and $k$-opioid receptors are coexpressed on at least some DRG neurons and appear to be functionally coupled to a common pool of calcium channels.
\end{abstract}

Both rapidly inactivating (transient) and sustained components of high-threshold current, arising from pharmacologically distinct types of calcium channels, were identified in our neurons. Activation of $\mu$-opioid receptors selectively reduced the transient component of currents evoked at +10 $\mathrm{mV}$ from $V_{h}=-80 \mathrm{mV}$, while sparing the sustained component. The transient component was irreversibly blocked by the $\mathrm{N}$-type channel antagonist $\omega$-conotoxin GVIA ( $\omega$-CgTx), and in one-half of the neurons there was a concomitant loss of the response to PLO17. In the remaining neurons, PLO17 continued to reduce a small fraction of $\omega$-CgTx-insensitive current and subsequent administration of the L-type channel blocker nifedipine in saturating concentrations failed to reduce the opioid-induced inhibitory effect. These data demonstrate that $\mu$-opioid receptors are negatively coupled to several pharmacologically distinct types of calcium channels in DRG sensory neurons, one that was blocked by $\omega$-CgTx and thus likely to be $\mathrm{N}$-type, and a second that was resistant to blockade by $\mathrm{N}$ - and L-type channel blockers.

\footnotetext{
Received June 4, 1993; revised Feb. 28, 1994; accepted Mar. 15, 1994.

We thank Ms. Rebecca Piltch for providing technical assistance. This work was supported in part by National Institute on Drug Abuse Grants DA03365 to H.C.M. and DA-04122 to R.L.M.

Correspondence should be addressed to Dr. Hylan C. Moises, Department of Physiology, University of Michigan Medical School, Ann Arbor, MI 48109-0622. Copyright (c) 1994 Society for Neuroscience $0270-6474 / 94 / 145903-14 \$ 05.00 / 0$
}

[Key words: $\mu$-opioid receptors, $\kappa$-opioid receptors, highthreshold $\mathrm{Ca}^{2+}$ current, $\omega$-conotoxin GVIA, DRG sensory neurons]

Opiates and opioid peptides exert their actions on the nervous system via three major classes of opioid receptors, consisting of the commonly accepted $\mu$-, $\delta$-, and $\kappa$-subtypes (see North, 1986, for review). A prominent effect that is associated with the activation of each of these receptors is a reduction in calciumdependent neurotransmitter release. Although it remains unclear how this presynaptic inhibitory action might be manifested, measurements obtained from neuronal somata suggest that the various subtypes of opioid receptor might produce their effects via a common ionic mechanism by reducing calcium entry through voltage-activated calcium channels. Thus, stimulation of $\kappa$-opioid receptors has been shown to inhibit calcium channcl currents directly in voltage-clamp recordings from peripheral sensory and spinal cord neurons (Macdonald and Werz, 1986; Gross and Macdonald, 1987; Bean, 1989a; Gross et al., 1990a; Sah, 1990) and to reduce calcium influx in spinal cord-dorsal root ganglion cocultures (Attali et al., 1989). Suppression of calcium currents has also been demonstrated after activation of $\delta$-opioid receptors in guinea pig submucosal neurons (Surprenant et al., 1990) and in neuroblastoma-glioma NG108-15 hybrid cells (Tsunoo et al., 1986; Hescheler et al., 1987; Taussig et al., 1992). Although the predominant effect produced in neurons by $\mu$-opioid receptors is an increase in membrane potassium conductance (Pepper and Henderson, 1980; Werz and Macdonald, 1983; North and Williams, 1985; North et al., 1987; Loose and Kelley, 1990; Wimpey and Chavkin, 1991), recent studies have revealed a direct suppression of whole-cell calcium currents after $\mu$-opioid receptor activation in rat DRG sensory neurons (Schroeder et al., 1991, 1993). It should be noted that $\kappa$-opioid receptors have been shown previously to be negatively coupled to calcium channels in these same neurons (Macdonald and Werz, 1986; Gross and Macdonald, 1987). Hence, these new data raise the possibility for convergent modulation of calcium channel function by more than one type of opioid receptor. Interestingly, $\mu$-opioid receptors have also been reported to inhibit calcium currents in the SH-SY $5 Y$ human neuroblastoma cell line; however, this effect is not produced by stimulation of $\delta$-opioid receptors (Seward et al., 1991).

Mammalian sensory neurons are known to express multiple types of calcium channels, including those which contribute the transient low-threshold (T), transient high-threshold $(\mathrm{N})$, and slowly inactivating/sustained high-threshold (L) components of whole-cell current (reviewed in Tsien et al., 1988; Bean, 1989b; 
and see Schroeder et al., 1990a; Regan et al., 1991; McCarthy and TanPiengco, 1992; Scroggs and Fox, 1992). T-currents are readily distinguishable from the higher-threshold components by kinetic and voltage-dependent criteria (Nowycky et al., 1985; Carbonne and Lux, 1987; Fox et al., 1987a,b; Schroeder et al., 1990b; Scroggs and Fox, 1992). In addition, there is general agreement that dihydropyridine-sensitive sustained and $\omega-\mathrm{CgTx}-$ sensitive transient high-threshold current components are associated with the activation of L- and N-type channels, respectively (Aosaki and Takai, 1989; Hess, 1990; Regan et al., 1991; McCarthy and TanPiengco, 1992). Previous work from this and other laboratories has shown that $k$-selective opioid peptides preferentially inhibit a rapidly inactivating component of highthreshold current in rat sensory neurons (Gross and Macdonald, 1987; Bean, 1989a; Gross et al., 1990a; Sah, 1990). By relying on variations in holding and test potential to separate kinetically distinct components of high-threshold current arising from multiple channel types, it was inferred that the opioid-sensitive current was carried through $\mathrm{N}$-type channels. Schroeder et al. (1991) reported that a transient, $\omega$-CTX-sensitive component of high-threshold current was reduced by activation of $\mu$-opioid receptors in rat DRG neurons, but in their cells $T$-currents were also affected by $\mu$-opioids (Schroeder et al,, 1991). On the other hand, slowly inactivating components of high-threshold current appear to be relatively resistant to inhibition by either $\mu$ - or $\kappa$-opioids, although sensitivity of these currents to dihydropyridines was not tested in any of the studies (Gross and Macdonald, 1987; Gross et al., 1990; Schroeder et al., 1991). Thus, it remains uncertain whether $\mathrm{N}$-type channels alone provide the primary target for inhibitory modulation by $\mu$-opioid receptors in DRG sensory cells. In fact, recent findings that these cells, like many other mammalian neurons, express an additional transient component of high-threshold current that is insensitive to dihydropyridines and $\omega-\mathrm{CgTx}$ (Regan et al., 1991; Mintz et al., 1992a; Scroggs and Fox, 1992) raise the possibility that other channels types, such as $P$ channels, might contribute a significant portion of whole-cell calcium current that is modulated by opioids.

The dual expression of $\mu$ - and $\kappa$-opioid receptor coupling to calcium conductances in rat DRG neurons raises additional important questions about the nature of calcium channel modulation by opioids. Spccifically, do $\mu$ - and $\kappa$-opioid receptors modulate a common pool of channels, or is there evidence for a segregation of channels that are targeted by each receptor type? What type or types of calcium currents are modulated by $\mu$-opioid-selective agonists, and is the profile of targeted channels the same as that described for $\kappa$-opioids? To address these issues, we examined the effects of PLO17, a $\mu$-opioid receptor-selective agonist (Chang et al., 1983; Blanchard et al., 1987), on calcium currents in acutely dissociated rat DRG neurons using the wholecell variation of the patch-clamp technique (Hamill et al., 1981). The effects of PLO17 were compared with those produced by $\kappa$ - or $\delta$-opioid receptor-selective agonists and tested on distinct components of the whole-cell current that were distinguished by their differing kinetics, voltage dependency, and sensitivity to the calcium channel blockers nifedipine and $\omega$-CgTx. We show that $\mu$ - and $\kappa$-but not $\delta$-opioid receptors are coupled to calcium channels in DRG neurons, and that $\mu$-opioid receptor activation selectively reduces high-threshold transient current, thus mimicking effects demonstrated previously for $\kappa$-opioid receptors (Gross and Macdonald, 1987). Evidence is also presented that $\mu$-opioid receptors may inhibit two types of high- threshold calcium channels, one that is $\omega-\mathrm{CgTx}$ sensitive and a second that is resistant to both the toxin and dihydropyridines.

\section{Materials and Methods}

Preparation of acutely dissociated neurons. Dorsal root ganglia were dissected from the lumbar and thoracic regions of 21-30-d-old rats and placed in a culture dish on ice containing minimal essential medium (MEM) with Earle's salts (GIBCO Laboratories, Grand Island, NY), supplemented with glucose $(28.2 \mathrm{~mm}), \mathrm{NaHCO}_{3}(16.5 \mathrm{~mm})$, penicillin $(5 \mathrm{U} / \mathrm{ml})$, and streptomycin $(5 \mu \mathrm{g} / \mathrm{ml})$. The ganglia were treated with collagenase Type II (Sigma Chemical Co.; $3 \mathrm{mg} / \mathrm{ml}$ in MEM), for 50 min at $37^{\circ} \mathrm{C}$, followed by an additional $10 \mathrm{~min}$ period of incubation in trypsin type I (Sigma Chemical Co.; $1 \mathrm{mg} / \mathrm{ml}$ in MEM). The dispersed ganglia were transferred to a conical tube containing $5 \%$ bovine serum albumin ( $80 \mathrm{mg}$ in $4 \mathrm{ml}$ of MEM) to inhibit the enzymes and centrifuged at $500 \times g$ for $5 \mathrm{~min}$ at $4^{\circ} \mathrm{C}$. Dissociated ganglia were resuspended in a $1.5 \mathrm{ml}$ aliquot of fresh medium, centrifuged a second time $(5 \mathrm{~min}$ at $250 \times g$ ), and then mechanically dispersed by triturating for four to five passages through a fire-polished Pasteur pipette. Cell suspensions were plated $(\sim 200 \mu \mathrm{l} / \mathrm{dish})$ onto collagen-coated culture dishes and incubated at $37^{\circ} \mathrm{C}$ for $1 \mathrm{hr}$, after which an additional amount of MEM containing 10\% horse serum (Sigma Chemical Co.) and nerve growth factor $(50 \mathrm{ng} / \mathrm{ml}$; Boehringer Mannheim, Indianapolis, IN) was added to bring the total volume to $2 \mathrm{ml} / \mathrm{dish}$. In roughly $90 \%$ of the experiments, cells were studied between 2 and $10 \mathrm{hr}$ after plating, and in the remaining cases within the first $2 \mathrm{~d}$ in culture. Cells maintained for more than $1 \mathrm{~d}$ in culture often began to extend processes, and therefore were excluded from the analysis if the recordings showed any sign of inadequate space clamp (e.g., delayed settling of capacitance transient with time constants of $>150 \mu \mathrm{sec}$ and broad tail currents).

Whole-cell patch-clamp recordings. Voltage-clamp recordings were obtained using the whole-cell variation of the patch-clamp technique (Hamill et al., 1981). Glass recording patch pipettes, prepared from Fisher brand microhematocrit tubes and having resistances of $0.8-2.5$ $\mathrm{M} \Omega$, were filled with recording solution of the following composition (in $\mathrm{mM}$ ): $140 \mathrm{CsCl}, 10 \mathrm{HEPES}, 10 \mathrm{EGTA}, 5 \mathrm{ATP}$ (magnesium salt), and 0.1 GTP (lithium salt) (all reagents from Sigma Chemical). The pH was adjusted with $1 \mathrm{M}$ CsOH to 7.3-7.35 after the addition of ATP and the osmolality ( $280-300 \mathrm{mOsm})$ adjusted to $10-15 \%$ below that of the bath solution. The neurons were bathed in a solution $(\mathrm{pH} \mathrm{7.4,310-330}$ mOsm) consisting of (in mM) 67 choline chloride, 100 tetraethylammonium chloride, $5.3 \mathrm{KCl}, 5.6$ glucose, $5.0 \mathrm{CaCl}_{2}, 0.8 \mathrm{mgCl}_{2}$, and 10 HEPES. Under these conditions sodium and potassium currents were suppressed. In the presence of $200 \mu \mathrm{M} \mathrm{Cd}^{2+}$ to eliminate the calcium currents, no voltage-dependent outward currents were evoked at test potentials as positive as $+30 \mathrm{mV}$. In some experiments, $\mathrm{Ba}^{2+}(2 \mathrm{mM})$ was used in place of $\mathrm{Ca}^{2+}$ as the charge carrier.

Recordings were made at room temperature using an Axopatch 1-D patch-clamp amplifier (Axon Instruments, Foster City, CA). Pipette and whole-cell capacitance and series resistance were corrected using compensation circuitry on the patch-clamp amplifier. Initial input resistances were in the range of $500 \mathrm{M} \Omega$ to $1 \mathrm{G} \Omega$. Series resistance was routinely estimated by cancellation of the capacitance-charging current transient after patch rupture. In approximately $20 \%$ of the neurons ( $n$ $=34$ ), series resistance was also calculated from the $\mathrm{R}-\mathrm{C}$ time constant of the capacitative transients generated during a $10 \mathrm{mV}$ hyperpolarization (measured after zeroing of the pipette capacitance and with low pass filtering set at $20 \mathrm{kHz}$ ), using the following formula: series resistance = capacitance time constant/membrane capacitance (for details, see Scroggs and Fox, 1992). In all cases, series resistance compensation of $75-90 \%$ was obtained without inducing significant noise or oscillation, resulting in final series resistances ranging from 0.15 to $1.8 \mathrm{M} \Omega$. Only data from neurons with low series resistance and currents small enough to maintain an error of less than $5 \mathrm{mV}$ in voltage commands were included in the analysis. In addition, data were discarded if the current trace showed any signs of problems with series resistance such as a slow tail current.

Voltage step commands of $100 \mathrm{msec}$ duration were applied every 30 or $60 \mathrm{sec}$ and the evoked currents filtered with a 12 pole low pass Bessel filter at $10 \mathrm{kHz}(-3 \mathrm{~dB})$. In later experiments, where commands of 500 or $1000 \mathrm{msec}$ were used, it was sometimes necessary to extend the period between test pulses to avoid accumulating inactivation. The filtered current records were digitized at $5 \mathrm{kHz}$, stored and analyzed by a 386based microcomputer using the program pCLAMP (Axon Instruments, 
A

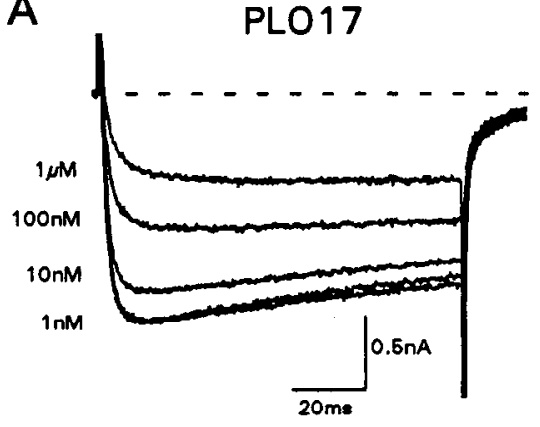

$V h=-80 m V \quad V c=+10 m V$

B

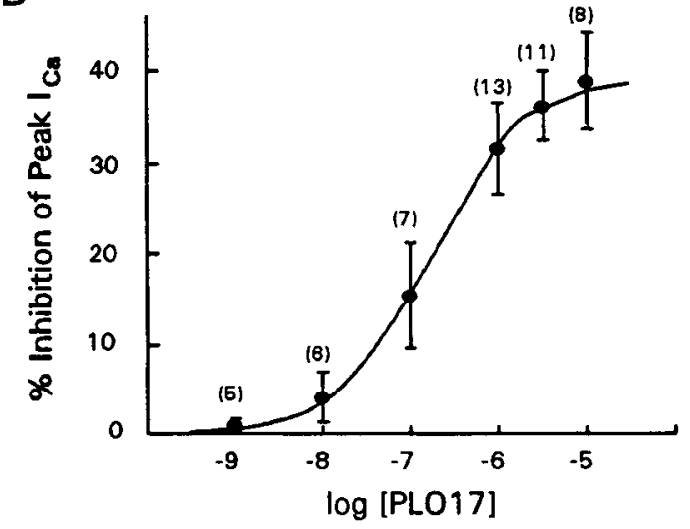

C

Control

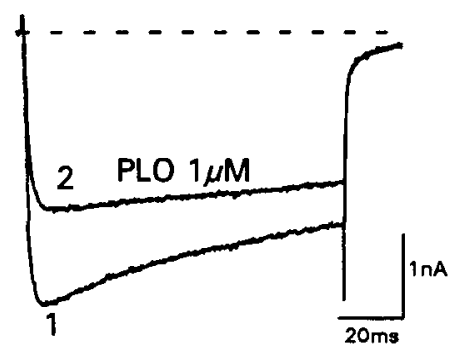

Naloxone $1 \mathrm{nM}$

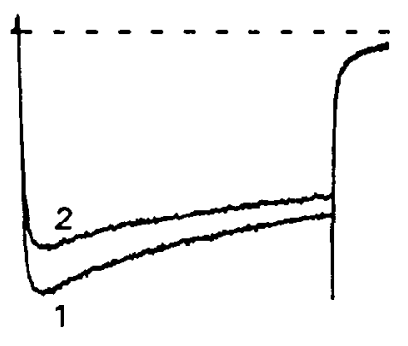

Naloxone 10nM

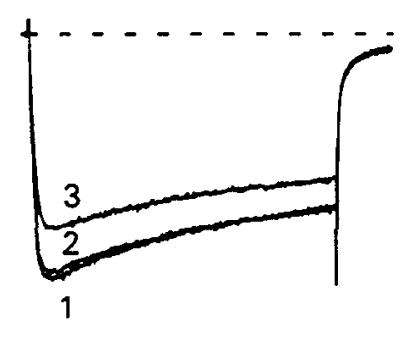

Figure 1. PLO17 inhibited calcium currents in a concentration-dependent and naloxone-reversible manner. $A$, Ensemble of whole-cell calcium channel currents evoked in a single DRG neuron by $100 \mathrm{msec}$ steps to $+10 \mathrm{mV}$ from $V_{h}=-80 \mathrm{mV}$ before and in the presence of increasing concentrations of PLO17 (1-1000 nM). Brief pressure applications ( $5 \mathrm{sec}$ at $1 \mathrm{psi}$ ) of the $\mu$-opioid agonist at concentrations $>10 \mathrm{~nm}$ reduced current amplitude and slowed the rate of current activation. $B$, Concentration-response curve for the PLO17-induced inhibition of calcium current obtained by pooling results from a number of cells. Points in the plot represent the mean \pm SEM of the values obtained from the number of cells given in the parentheses. The solid line connecting the points represents the best fit of the data by computer to a general logistic function (see text for details). $C$, Current traces from another cell show that the inhibition of calcium current by $1 \mu \mathrm{M}$ PLO17 was completely reversed by low nanomolar concentrations of the nonselective opioid antagonist naloxone. Numbered traces indicate currents evoked before $(I)$ and during (2) PLO17 and during application of the agonist after washout of naloxone (3).
Foster City, CA). Calcium currents evoked with 100 msec test pulses and with longer-duration commands were corrected for leak and capacitative currents using two different methods. In the former cases, leak current was estimated as the inverse of the current evoked with $100 \mathrm{msec}$ hyperpolarizing commands of equal magnitude to the depolarizing commands used to evoke the inward currents. This current was digitally subtracted from the relevant inward current to obtain the calcium current. Calcium currents evoked with 500- or 1000-msecduration commands were corrected for leak and capacitative currents by a $P / 4$ routine that involved subtraction of an appropriately scaled current elicited by a series of four small hyperpolarizing steps, whose sum was equal in magnitude to the depolarizing test pulse. In many cases, $\mathrm{Cd}^{2+}(200-500 \mu \mathrm{M})$ was applied to the cell at the end of an experiment and always eliminated the inward calcium currents, including any that remained in the presence of opioid agonists or calcium channel blockers.

Calculations of the magnitude of opioid-induced current inhibition were corrected for the decline in recordable calcium current (rundown) that often occurred during the course of whole-cell recording. The rate of rundown varied from neuron to neuron and tended to decrease over time, with control currents declining by $10-35 \%$ (average of $17.3 \pm$ $4.5 \%, n=42$ ) from the maximal peak current over a $25 \mathrm{~min}$ period of recording. To adjust for rundown, recovery currents were elicited following termination of agonist application until the amplitude of the postdrug currents had plateaued. The response to drug was then expressed as a percentage change in the averaged value of the predrug current and stabilized recovery current amplitudes. This adjustment relies on the fact that the establishment of agonist-induced inhibition in current occurs sufficiently fast (typically within several seconds) that the extent of current rundown during this time contributes marginally, if at all, to the absolute reduction in current measured. For determination of agonist dose-response relationships, testing of multiple concentrations of an opioid on individual neurons was carried out in randomized fashion so that any confounding effects due to current rundown would be averaged out.

Drug solutions and application. In the first phase of experiments, opioid agonists and antagonists were applied to the cell by using pressure ejection (6-10 pKa) from blunt-tipped (10-20 $\mu \mathrm{m}$ tip diameter) glass micropipettes positioned approximately $50 \mu \mathrm{m}$ from the cell. Agonist applications were 2-5 sec in duration and were delivered just before currents were evoked. When antagonists were administered to test for the specificity of agonist action, receptor-selective blockers were continuously weeped in the immediate vicinity of the cell from a large tipped puffer pipette ( $50 \mu \mathrm{m}$ tip diameter), in addition to being coadministered with the agonist by inclusion of these substances in the same puffer pipette. The drug-containing pipettes were removed from the bath when not in use. The pressure ejection technique allowed for the application of compounds to individual neurons, but did not allow determination of the exact concentration of test substances at the cell under study, a concentration that is likely to be severalfold less than the concentration in the pressure-ejection pipette. Of greater importance was the fact that this method effectively served to limit the duration of agonist-induced responses, allowing for the sequential testing of multiple concentrations of a single agent, as well as qualitative assessments of the actions of multiple agonist or antagonist substances on the same neuron.

In about a third of our experiments, including all cases where calcium channel blockers were used, a rapid-exchange U-tube system (modified from Murase et al., 1989) was used to change the solution bathing the cell under study. This consisted of a gravity fed U-shaped polyethylene tubing. The delivery port of the tube was positioned within $200 \mu \mathrm{m}$ of the cell, while the distal end was interfaced to a vacuum line by means of a digitally controlled switching valve. A laminar flow of control or drug-containing solution was maintained over the neuron throughout the recording, while the microenvironment around the cell could be rapidly exchanged by opening or closing the connection to the vacuum line.

PLO17, dynorphin A (prodynorphin 209-225, porcine), D-Pen 2.5 -enkephalin (DPDPE) and $\omega$-CgTx were obtained from Peninsula Laboratories (Belmont, CA). The opioids were prepared as $1 \mathrm{~mm}$ stock solutions in sterile water, partitioned into $10 \mu \mathrm{l}$ aliquots, lyophilized, and stored at $-20^{\circ} \mathrm{C}$. $\omega-\mathrm{CgTx}$ was prepared as a $500 \mu \mathrm{M}$ stock solution in sterile water and stored in the same manner. On the day of the experiment the dried aliquots, as well as the $k$-opioid agonist $(5 \alpha, 7 \alpha, 8 \beta)-(-)$ $N$-methyl- $N$-(7-(1-pyrrolidinyl)-1-oxaspiro(4,5)dec-8-

yl)benzeneacetamide (U69,593; Sigma Chemical) were dissolved in the extracellular bathing solution to the desired concentrations. Bovine serum albumin $(0.1 \%$; Sigma Chemical) was included in all solutions of dynorphin $A$ and DPDPE when the peptides were applied by pressure ejection. 
Figure 2. Calcium currents were inhibited by $\mu$ - and $\kappa$ - but not $\delta$-opioid agonists. $A$, Comparison of inhibitory effects of dynorphin A, PLO17, and DPDPE on calcium currents elicited in the same neuron by steps to $+10 \mathrm{mV}$ from $V_{h}^{r}=-80 \mathrm{mV}$ at times indicated after patch rupture. Calcium currents recorded before $(1)$, in the presence of an agonist (2), and $2 \mathrm{~min}$ after washout of drug (3) have been superimposed for purposes of comparison. Peptides $(1 \mu \mathrm{M}$ in all cases) were applied to the cell using uniform pressure ejection parameters ( 1 psi for $5 \mathrm{sec}$ ) from glass pipettes of equivalent tip diameter $(20 \mu \mathrm{m})$, and currents were evoked at a fixed latency $(3 \mathrm{sec})$ from the onset of drug ejection. $B 1$, Bar graph showing the pattern of inhibitory responses that were obtained to PLO17, dynorphin A $(D Y N)$ and DPDPE in 14 DRG neurons tested as in $A$. Among these 14 cells, two did not show an inhibition in calcium current by any of the opioids $(N R)$, two responded only to PLO17 (PIOO17), three responded only to dynorphin $\mathrm{A}(D Y N)$, and seven responded to both PLO17 and dynorphin A (PLO । DYN). By contrast, no cell showed an inhibition in calcium current by DPDPE. $B 2$, Bar graph shows the pattern of calcium current suppression obtained in 22 additional neurons during similar testing with PLO17 $(1 \mu \mathrm{M})$ and U69,593 $(3 \mu \mathrm{M})$.
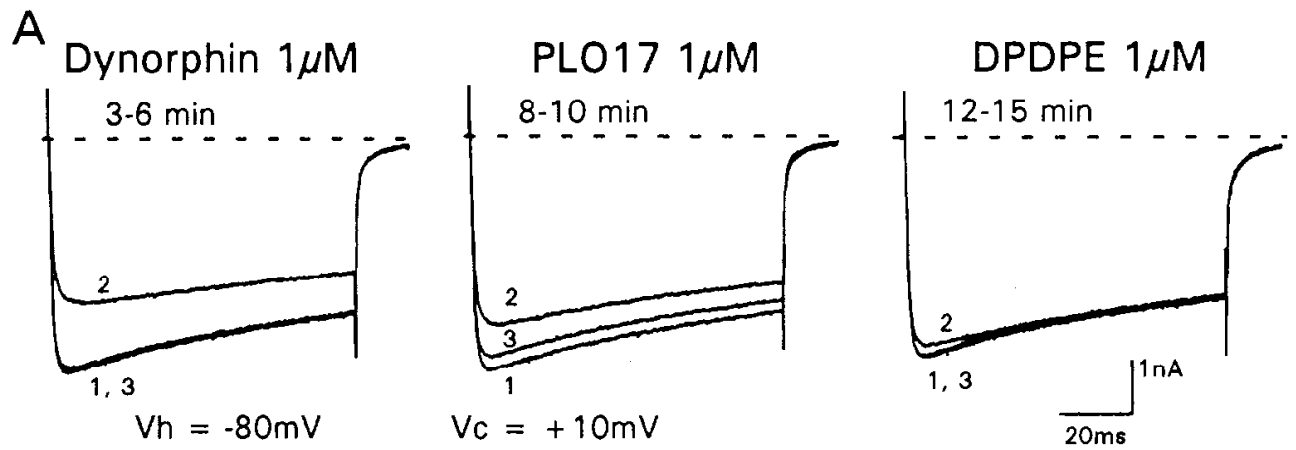

\section{B Cells Responding to Opioid Agonists}

1

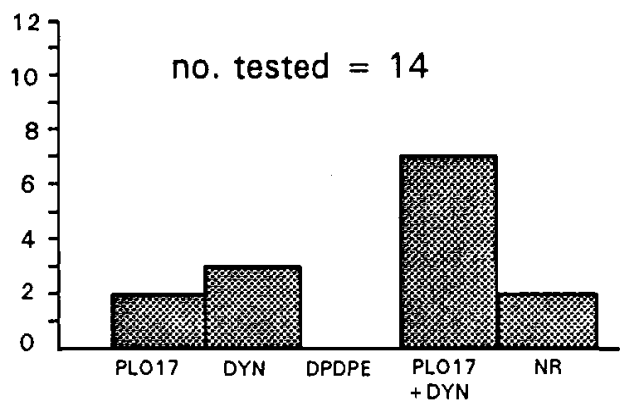

2

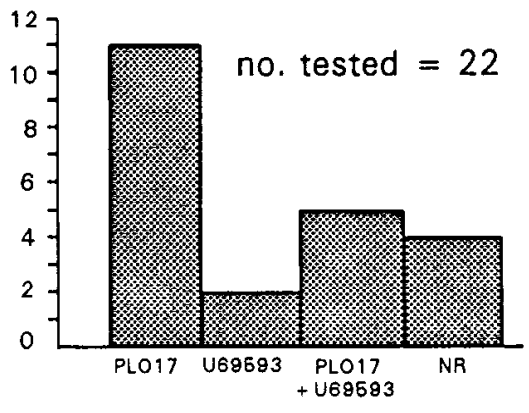

Nifedipine and the opioid receptor antagonists naloxone, nor-binaltorphimine (nor-BNI), and $\beta$-funaltrexamine $(\beta$-FNA) were obtained from Research Biochemicals Inc. (Natick, MA). $\beta$-FNA was prepared as a $1 \mathrm{~mm}$ stock solution in methanol and stored at room temperature for a maximum of 1 week. On the day of the experiment, experimental solutions of these drugs were prepared to the desired concentrations by dilution with extracellular bath solution. To minimize degradation caused by exposure to light, nifedipine was held in a light-proof container and routinely applied to the recording chamber under restricted light conditions.

Statistical comparisons. Statistical comparisons between control and experimental values were made using either a Student or paired twotailed $t$ test. Values in text are given as mean \pm SEM, unless otherwise indicated.

\section{Results}

Application of the $\mu$-opioid receptor-selective agonist PLO17 (300-3000 nм) (Chang et al., 1983; Blanchard et al., 1987), reversibly reduced calcium channel currents in 171 of $228 \mathrm{DRG}$ neurons (Figs. 1, 2). Neurons in which calcium currents were reduced less than $10 \%$ by the agonist $(n=37)$ or where inhibition of the current did not exceed the general rate of current rundown ( $n=20$, rundown corrected for as described in Materials and Methods) were considered to be unresponsive to $\mu$-opioids. The proportion of responsive neurons we observed was only slightly lower than that found in short-term cultures of DRG neurons from adult rats ( $88 \%$ responded to $\mu$-opioids) (Schroeder et al., 1991). Since the preparations used in both studies contained a helerogenous population of sensory neurons, these results suggest that there may be little difference in the expression of $\mu$-opioid receptors among DRG neurons that encode distinct modalities of sensation (also see Schroeder and McCleskey, 1993).

The ensemble of traces in Figure $1 A$ illustrates the inhibition of calcium current produced by a $5 \mathrm{sec}$ puffer application of PLO17, applied at concentrations from 1-1000 nM. Calcium currents were elicited at $1 \mathrm{~min}$ intervals in the absence or presence of the $\mu$-opioid agonist by 100 msec steps to $+10 \mathrm{mV}$ from $V_{h}=-80 \mathrm{mV}$. At this holding potential, low-threshold T-type currents were at least partially inactivated, and except in the case of neurons with giant T-currents (see below), accounted for less $10 \%$ of the total whole-cell current (see Gross and Macdonald, 1987; Schroeder et al., 1990a; but see Scroggs and Fox, 1992). By comparison, the majority of the whole-cell current in rat DRG neurons consisted of high-threshold current, which could be resolved here, as in other studies (Fox et al., 1987a; Gross and Macdonald, 1987; Schroeder et al., 1990b; Regan et al., 1991) into several kinetically distinct components. The presence of both rapidly inactivating (i.e., transient) and slowly inactivating or sustained components of high-threshold calcium current was evident in currents evoked by $100 \mathrm{msec}$ commands, as shown for example in Figure $1 C$, while their respective contributions to the whole-cell current were readily apparent using steps of 300-1000 msec duration (see, e.g., Fig. 6 A). In the earlier studies, the inactivating or transient components of high-threshold current were assigned to N-type channels, while the more sustained components were attributed to L-type channel activity, based in part on their sensitivity to dihydropyridines (Nowycky et al., 1985; Fox et al., 1987a; Gross and Macdonald, 1987). Recent analyses of single-channel activity have revealed, howcver, that the same $\mathrm{N}$-type channel can give rise to both inactivating and noninactivating behavior (Plummer and Hess, 1991). Therefore, reference to the transient and sustained components of high-threshold calcium current is made here without assignment to particular channel types, unless these distinctions were 
also confirmed by determination of their respective pharmacological sensitivities. To quantitate the inhibition of calcium current by PLO17, we measured the effect of the agonist on the maximal current occurring within $8-15 \mathrm{msec}$ after onset of the voltage step, referred to here simply as the peak current $\left(I_{p}\right)$, without regard to the relative contributions of high-threshold transient and sustained current components to the peak. PLO17 inhibited the current in a concentration-dependent manner (Fig. 1A). At each concentration the effect of PLO17 was rapid in onset, occurring within a few seconds after application (2 sec being the shortest delay examined between drug delivery and evoking currents). No evidence of desensitization of the response to PLO17 was observed either during prolonged applications or with successive trials on the same cell, even with concentrations as high as $30 \mu \mathrm{M}$ (data not shown).

The extent of calcium current inhibition by PLO17 varied considerably among sensitive neurons (10-90\% of $I_{p}$, range for $n=55$ at $3 \mu \mathrm{M}$, mean $=37.3 \pm 3.4 \%$ ). Therefore, to construct a full concentration-response curve we pooled data from a selected number of neurons that were tested with a minimum of four agonist concentrations, including that which yielded a maximal inhibitory effect. As shown by the concentration-inhibition curve in Figure $1 B$, the threshold response to PLO17 was obtained at $10 \mathrm{nM}$ and neither inhibition nor enhancement (see, e.g., Shen and Crain, 1989) of the current was observed at lower agonist concentrations. In addition, $3 \mu \mathrm{M}$ PLO1 7 represented a near saturating concentration in that responses to $10 \mu \mathrm{M}$ were not significantly greater in the same neuron, and at saturating concentrations PLO17 only partially suppressed the peak calcium current; the maximum inhibition produced by 3-10 $\mu \mathrm{M}$ of the agonist being $38.4 \pm 4.4 \%$ (mean $\pm \mathrm{SEM}, n=19$ ). When the data in Figure $1 B$ were fit by computer to the general logistic equation $R / M=[A]^{n} /[A]^{n}+K^{n}$, where $R$ is the response, $M$ is the maximal response, $[A]$ is the concentration of agonist, and $K$ and $n$ are fitting parameters, the concentration of PLO17 producing half-maximal inhibition $\left(\mathrm{EC}_{50}\right)$ of the current was calculated to be $168 \mathrm{nM}$, with the slope slightly less than unity ( $n=0.82$; correlation coefficient $>0.95$ ). It should be noted that the actual $\mathrm{EC}_{50}$ for PLO17 was likely to be somewhat lower, since a substantial dilution in final concentrations of the agonist at receptor sites can be anticipated with puffer delivery of drugs to neurons maintained in a $1-2 \mathrm{ml}$ volume bath.

The inhibition of calcium current by PLO17 was often associated with a marked slowing in the rate of current activation (Fig. $1 A$; see also Fig. $7 A$ ). For example, in 31 of 55 neurons that responded to $3 \mu \mathrm{M}$ PLO17, the time to peak amplitude in currents evoked from $V_{h}=-80 \mathrm{mV}$ increased from $10.6 \pm 0.4$ msec (8-14 msec range) to $36.3 \pm 2.7 \mathrm{msec}$ (21-90 msec range; $p<0.01)$. The slowing of current activation was particularly evident in neurons that were tested using the agonist at or near saturating concentrations, and thus the likelihood of occurrence of the phenomenon as observed here was probably underestimated. This effect of $\mu$-opioid receptor activation was indistinguishable for the slowed turn-on of neuronal high-threshold calcium currents that was produced by the $\kappa$-opioid agonist, dynorphin $\mathrm{A}$, and by several other neurotransmitters whose receptors are known to be coupled in an inhibitory manner to calcium channels via G-proteins (Bean, 1989a; Gross et al., 1990a; see also Tsien et al., 1988, for a review). In approximately one-third of the neurons, $\mu$-opioid-induced inhibitions in current were accompanied as well by a transient runup in current amplitude above control after washout of the drug (e.g., see Figs.
$4 B, 7 B)$. A similar rebound facilitating effect has been described for the $\delta$-opioid agonist DPDPE in NG108-15 cells (Kasai, 1991), and has been attributed to the removal of "tonic inhibition" in calcium channel activity imposed presumably by constituent activation of G-proteins. It should be noted that control current values were derived by averaging the amplitudes of the predrug current and stabilized recovery current (see Materials and Methods), and therefore such runup in current after agonist washout would not bias our measurements of responses to opioids.

\section{Mediation of PLO17 effects by $\mu$-opioid receptors}

Administration of the opiate antagonist naloxone blocked ( $n=$ $16)$ or reversed $(n=10)$ the inhibition of calcium current by PLO17 in all neurons examined with an $\mathrm{IC}_{50}$ of approximately $1 \mathrm{nM}$ (tested against $1 \mu \mathrm{M}$ agonist). In the neuron shown in Figure $1 C$, for example, the inhibitory effect of PLO17 $(1 \mu \mathrm{M})$ was reduced $47.6 \%$ (from $34.2 \%$ to $17.9 \%$ inhibition of $I_{p}$ ) by $1 \mathrm{~nm}$ naloxone and blocked completely by $10 \mathrm{nM}$ naloxone. Overall, application of naloxone (100 $\mathrm{nm}$ ) reduced the mean inhibition in peak current produced by $1 \mu \mathrm{M}$ PLO17 by $91.5 \%$ (from 24.7 $\pm 4.5 \%$ to $2.1 \pm 0.2 \%, n=16$ ). Although the high sensitivity of this PLO17 effect to blockade by naloxone is indicative of its mediation via $\mu$-opioid receptors (see North, 1986), such findings would not preclude the involvement of other types of opioid receptors, particularly when micromolar concentrations of the agonist are administered, as was often the case here. Therefore, we further characterized the receptor subtype mediating the inhibition of calcium current by PI 017 by comparing its action with those of $\kappa$ - or $\delta$-opioid-selective agonists and using $\mu$-selective and $\kappa$-selective opioid antagonists to block its effects.

The abilities of $\mu-, \kappa^{-}$, and $\delta$-selective agonists to inhibit calcium current were compared in the same cell $(n=14)$ by delivering equivalent $5 \mathrm{sec}$ applications of each drug at a concentration of $1 \mu \mathrm{M}$ in randomized order. PLO17 and the $\kappa$-opioid agonist dynorphin A (Chavkin et al., 1982; James et al., 1983) reversibly reduced the current evoked by steps to $+10 \mathrm{mV}$ from $V_{h}=-80 \mathrm{mV}$, whereas the $\delta$-selective agonist D-Pen ${ }^{2.5}$-enkephalin (DPDPE) (Mosberg et al., 1983) was essentially without effect (Fig. 2A). As summarized by the bar graph in Figure $2 B 1$, DPDPE had no significant effect on calcium currents in any of the neurons examined, even when administered at concentrations up to $10 \mu \mathbf{M}$ (data not shown). Thus, it was unlikely that PI.017 exerted its effects through $\delta$-opioid receptors. It was more difficult to exclude an involvement of $\kappa$-opioid receptors, since agonists for these receptors clearly inhibited the calcium current (Figs. 2-4), and in half of the neurons tested currents were reduced by both PLO17 and dynorphin A (Fig. 2B1). However, since some neurons that responded to PLO17 $(n=$ 2) showed no inhibition of current by dynorphin $A$ and responsiveness to dynorphin A alone was similarly expressed in DRG neurons ( $n=3$ ), it was likely that the effects of PLO17 were not mediated via $\kappa$-opioid receptors. Furthermore, when sensitivity of DRG neurons to PLO17 $(1 \mu \mathrm{M})$ and to the highly selective $\kappa$-opioid agonist U69,593 (3 $\mu \mathrm{M}$; Lahti et al., 1985) was directly compared, we found that a high percentage of neurons responded only to the $\mu$-opioid (11 of 22) (Fig. 2B2). Among seven additional neurons that were sensitive to opioids werc two that responded only to the $k$-opioid agonist, whereas five showed an inhibition in calcium current by either drug.

To confirm that the inhibition of calcium current by PLO17 was mediated via activation of $\mu$-opioid receptors, we deter- 
A

PL017 $1 \mu \mathrm{M} \quad \mathrm{U} 69,5933 \mu \mathrm{M} \quad$ BFNA $300 \mathrm{nM} \quad$ PL017: U69,593

Figure 3. Calcium current inhibition by PLO17 was lost after irreversible blockade of $\mu$-opioid receptors: calcium currents (traces) elicited by $100 \mathrm{msec}$ steps to $+10 \mathrm{mV}$ from $V_{h}=-80 \mathrm{mV}$ $(A)$ at the times indicated in the graph $(B)$ of peak current versus time after patch rupture. On initial application (5 sec at 1 psi) PIO 17 at $1 \mu \mathrm{M}$ (trace 2) and $\mathrm{U} 69,593$ at $3 \mu \mathrm{M}$ (trace 4), a $\kappa$-selective agonist, produced roughly comparable inhibitory effects on calcium current, reducing peak current amplitude by 1.3 and $1.1 \mathrm{nA}$, respectively. Prolonged application of $\beta$-FNA at 300 nM $(2.5 \mathrm{~min}$ delivery via a $50-\mu \mathrm{m}$-diameter tip weeper pipette) also reversibly reduced current amplitudes (trace 6 ), although to a much lesser extent. Following washout of $\beta$-FNA, control currents recovered back toward predrug levels; however, reapplication of PLO17 $1 \mu \mathrm{M}$ (trace 7) was now without effect. In comparison, U69,593 (3 $\mu \mathrm{M}$, trace 8 ) inhibited the calcium current to nearly the same extent $(1.0 \mathrm{nA})$ as before $\beta$-FNA.
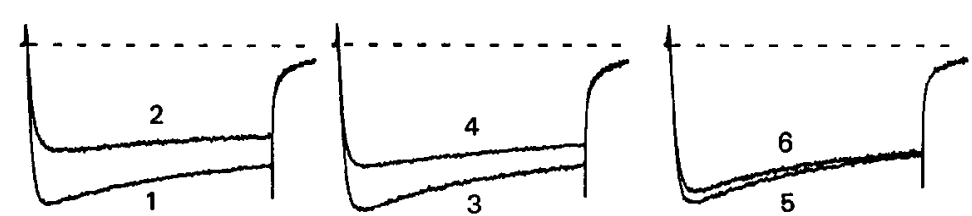
after BFNA

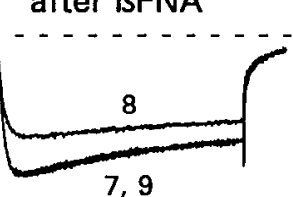

$V_{h}=-80 m V \quad V c=+10 m V$

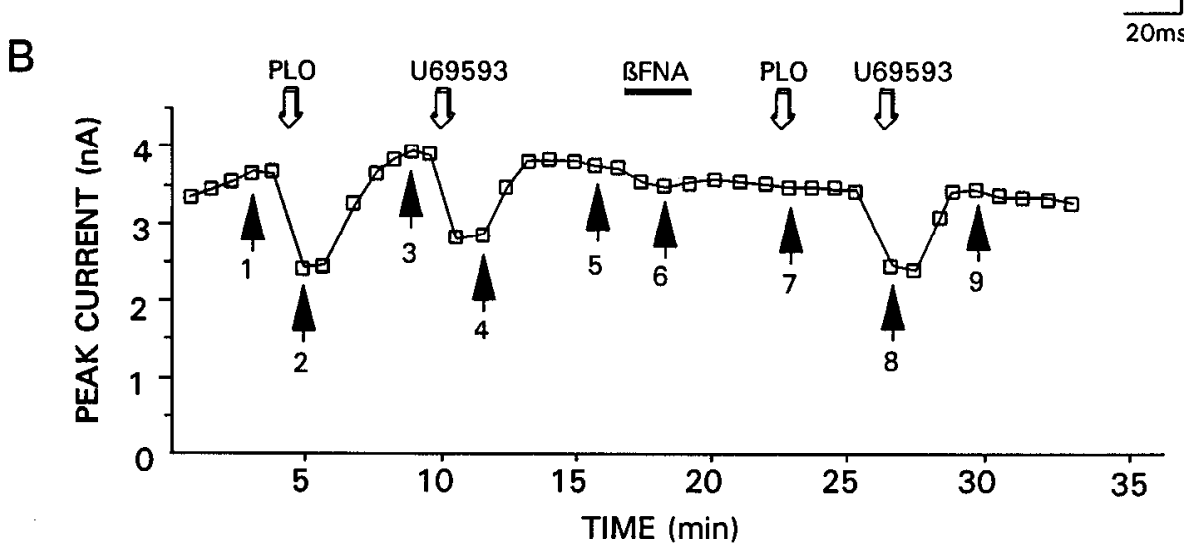

mined whether responses to PLO1 7 could be blocked selectively by $\mu$-but not $\kappa$-opioid-selective antagonists. Figure 3 shows the results of an experiment in which inhibition of calcium current produced by PLO17 or U69,593 was examined before and after administration of the irreversible $\mu$-opioid receptor antagonist $\beta$-FNA (Takemori et al., 1981). The currents depicted in Figure $3 A$ were recorded at the times indicated in the graph of peak calcium current versus time after patch rupture (Fig. $3 B$ ). Prior to the application of $\beta$-FNA (300 nM), PLO1 7 (1 $\mu \mathrm{M})$ and U69,593 $(3 \mu \mathrm{M})$ reduced $I_{p}$ amplitude to a similar extent (by 1.25 and 1.1 $\mathrm{nA}$, respectively). Administration of $\beta$-FNA alone for $2.5 \mathrm{~min}$ also reversibly reduced the calcium current, although to a much lesser extent $(0.2 \mathrm{nA})$, presumably as a result of its actions as a $\kappa$-opioid agonist (Takemori et al., 1981). Following recovery from the inhibitory effect of $\beta$-FNA, a subsequent application of PLO17 $(1 \mu \mathrm{M})$ had a negligible effect on the current, whereas the response to the $\kappa$-agonist remained largely intact (peak current reduced $1.0 \mathrm{nA}$ from 3.5 to $2.5 \mathrm{nA}$ ). Similar results were obtained in four additional cells examined in this manner, with mean reductions in calcium current before and after $\beta$-FNA $(300-1000 \mathrm{nM}, n=5)$ of $32.3 \pm 4.4 \%$ and $3.5 \pm 2.5 \%$ for PLO17 (1-3 $\mu \mathrm{M})$ versus $24.3 \pm 5.2 \%$ and $21.5 \pm 4.7 \%$ for U69,593 (1$3 \mu \mathrm{M})$. A quite different outcome was obtained in experiments $(n=7)$ in which the reversible and highly selective $k$-opioid receptor antagonist nor-BNI (Portoghese et al., 1987) was substituted for $\beta$-FNA. For example, as shown in Figure 4 , administration of nor-BNI ( $300 \mathrm{~nm}$ ) nearly abolished the inhibition of calcium current by dynorphin $\mathrm{A}$, reducing the suppression in $I_{p}$ amplitude from $1.3 \mathrm{nA}$ to $0.1 \mathrm{nA}$. However, it did not reduce the response to PLO17 $\left(I_{p}\right.$ was suppressed by $1.2 \mathrm{nA}$ and $1.1 \mathrm{nA}$ before and during nor-BNI, respectively) and was without effect on control currents. This same outcome was observed in five additional neurons and overall, administration of norBNI (300-1000 nM, $n=7$ ) blocked the dynorphin A-induced suppression in calcium current by $88 \pm 3.5 \%$ (from $35.7 \pm 3.8 \%$ to $4.3 \pm 1.2 \%$ inhibition in $I_{p}$ at $1-3 \mu \mathrm{M}$ ), while having little effect on responses to PLO17 (1-3 $\mu \mathrm{M}$ producing $28.5 \pm 4.5 \%$ and $26.2 \pm 3.9 \%$ inhibition in its absence and presence, respectively). Thus, we were able to conclude that the inhibitory effect of PLO17 on calcium channels was mediated via the activation of $\mu$-opioid receptors.

In neurons that responded to both $\mu$ - and $\kappa$-opioids, the relative potency of agonists for inhibiting calcium current was dynorphin A > PLO17 > U69,593 (based on comparisons of their effects at $1 \mu \mathrm{M}$; see above). On the other hand, application of a saturating concentration of each of these agonists produced qualitatively similar and nearly equivalent reductions in current in a given neuron (Table 1 , Fig. 3 ). This suggested the possibility that $\mu$ - and $\kappa$-opioid receptors coexpressed in the same neuron might regulate the activity of a common population of calcium channels. If true, this arrangement would predict that a $\mu$ - or $\kappa$-agonist would be more effective when administered alone than in the presence of the other agonist. It would also result in the nonadditivity of the individual inhibitory effects of PLO17 and dynorphin $A$ with respect to their combined action when administered together. This possibility was tested in six neurons by determining the inhibitory effects of near maximal concentrations of each agonist (PLO17 used at $3 \mu \mathrm{M}$ and dynorphin at 1 or $3 \mu \mathrm{M}$ ) first applied individually to a neuron and then administered together. In all cases, administration of one agonist in the continued presence of the other inhibited a fraction of calcium current that was significantly smaller than the magnitude of the current reduction produced when that agonist was tested alone. Similarly, in contrast to the marked inhibitory effect of the first agonist, administration of the second agonist in its presence induced either no or only a small further reduction in inward current, as summarized in Table 1. This same outcome was obtained in four additional neurons when the summation of responses to PLO17 ( $3 \mu \mathrm{M})$ and U69,593 was examined using saturating concentrations of both ligands (U69,593 


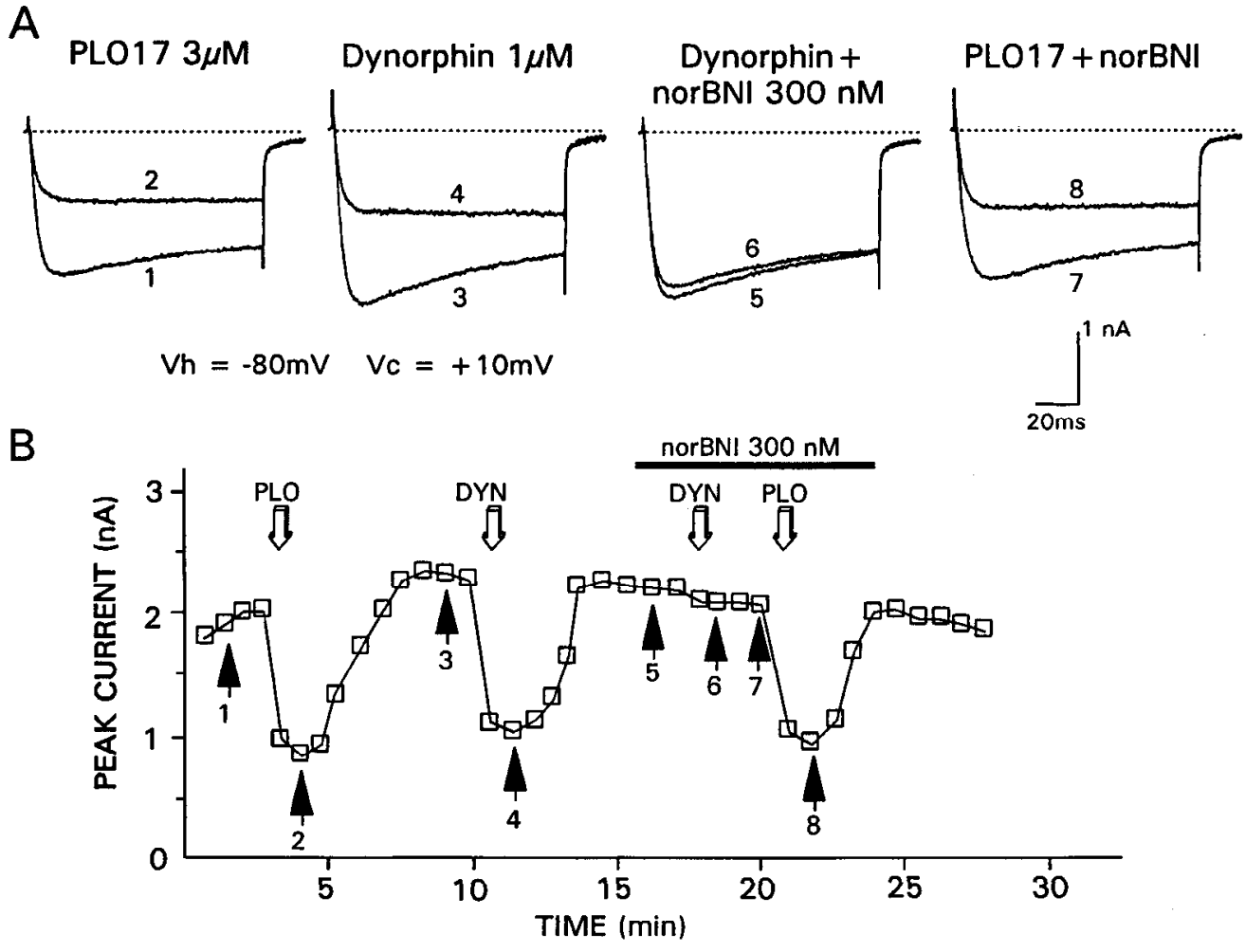

Figure 4. PLO17 did not act via $\kappa$-opioid receptors to inhibit calcium currents: calcium currents elicited in the same neuron by $100 \mathrm{msec}$ steps to +10 $\mathrm{mV}$ from $V_{h}=-80 \mathrm{mV}(A)$ at the times indicated in the graph $(B)$ of peak current versus time after patch rupture. Pairs of current traces from left to right compare the inhibitory effects on calcium current of PLO17 $(3 \mu \mathrm{M})$ and of dynorphin $A(1 \mu M)$ in the absence (traces 2 and 4, respectively) and presence (traces 6 and 8 ) of the $\kappa$-selective antagonist nor-binaltorphimine (nor$B N I)$ at $300 \mathrm{nM}$. Nor-BNI selectively blocked the response to dynorphin $A$ (reducing the suppression in current from 1.25 to $0.1 \mathrm{nA}$ ) without reduction in the effect of PLO17 (1.2 nA before vs $1.1 \mathrm{nA}$ after nor-BNI). The $\kappa$-selective antagonist was administered continuously to the cell during the period indicated by the solid bar in $B$. This cell responded to a third application of $\mathrm{dy}$ norphin A (data not shown) that was delivered $6 \mathrm{~min}$ after washout of the antagonist. used at $3 \mu \mathrm{M}$ and $10 \mu \mathrm{M})$. These results were obtained independently of whether the $\mu$-agonist $(n=5)$ or the $k$-agonist $(n=5)$ was administered first and whether drugs were applied to the neuron by puffer application or local superfusion.

\section{Selective inhibition of high-threshold transient currents}

The inhibitory effect of PLO1 7 was not represented by a uniform reduction in inward calcium current that was recorded over the duration of the test pulse. Rather, the peak current which was obtained within 8-15 msec after initiation of the voltage step was reduced by a greater amount than was the residual current $\left(I_{100}\right)$ that remained immediately prior to the termination of a $100 \mathrm{msec}$ depolarizing step (see, e.g., Figs. $3 A, 4 A$ ). Thus, among a sample of 55 neurons in which PLO17 was applied at saturating concentrations (3-10 $\mu \mathrm{M}), I_{p}$ was inhibited by an average of $42.6 \pm 2.3 \%( \pm \mathrm{SEM})$, whereas the reduction in $I_{100}$ averaged only $29.8 \pm 1.6 \%\left(p<0.05\right.$, compared to the reduction in $\left.I_{p}\right)$. In addition, whereas control currents elicited by $100 \mathrm{msec}$ steps to $+10 \mathrm{mV}$ from $V_{h}=-80 \mathrm{mV}$ were composed of both rapidly and slowly inactivating components, currents evoked in the presence of PLO17 (in near-maximal concentrations) often showed little or no decay during $100 \mathrm{msec}$ depolarizing commands (Figs. 1 $A, 4 A, 5 A$ ). This outcome might be expected if the effect of $\mu$-opioid receptor activation was to reduce selectively calcium currents that inactivate rapidly, while sparing those that exhibit sustained behavior during prolonged depolarization. To test this possibility, we examined the effects of PLO17 on isolated low-threshold T-type current and on kinetically distinct components of high-threshold current that were distinguished based on differences in their voltage dependence of inactivation. The results of these analyses are described in terms of transient and sustained components of high-threshold current, rather than using designations based on the $\mathrm{N}-$, L-, or P-type nomenclature, since the correct criteria for identification of multiple channel types that contribute these components of whole-cell current in neurons remains uncertain (see Fox et al., 1987a,b; Swandulla and Armstrong, 1988; Aosaki and Kasai, 1989; Plummer et al., 1989; Regan et al., 1991).

T-type currents were isolated by stepping to test potentials of

\begin{tabular}{|c|c|c|c|c|c|c|}
\hline Cell & PLO17 & $\begin{array}{l}\text { Dynor- } \\
\text { phin A }\end{array}$ & U69,593 & $\begin{array}{l}\text { Alge- } \\
\text { braic } \\
\text { sum of } \\
\mu \text { and } \\
\kappa \text { ago- } \\
\text { nists }\end{array}$ & $\begin{array}{l}\text { Coad- } \\
\text { minis- } \\
\text { tration } \\
\text { of } \mu \text { and } \\
\kappa \text { agonists }\end{array}$ & $\begin{array}{l}\text { Percen- } \\
\text { tage } \\
\text { pre- } \\
\text { dicted } \\
\text { effect }\end{array}$ \\
\hline 1 & 0.45 & 0.43 & & 0.88 & 0.52 & 59.1 \\
\hline 2 & 1.10 & 1.15 & & 2.25 & 1.52 & 67.6 \\
\hline 3 & 0.58 & 1.25 & & 1.25 & 0.82 & 65.6 \\
\hline 4 & 1.26 & 1.43 & & 2.69 & 1.48 & 55.0 \\
\hline 5 & 4.22 & 3.80 & & 8.02 & 4.52 & 56.4 \\
\hline 6 & 2.07 & 2.24 & & 4.31 & 2.32 & 53.8 \\
\hline Mean & 1.63 & 1.61 & & 3.24 & $1.86^{*}$ & $59.6^{*}$ \\
\hline SEM & 0.48 & 0.46 & & 0.66 & 0.49 & 1.0 \\
\hline 1 & 2.30 & & 2.19 & 4.49 & 2.40 & 53.5 \\
\hline 2 & 1.29 & & 1.41 & 2.70 & 1.48 & 54.8 \\
\hline 3 & 0.79 & & 0.75 & 1.54 & 0.84 & 54.6 \\
\hline 4 & 1.02 & & 0.95 & 1.97 & 1.10 & 55.8 \\
\hline Mean & 1.35 & & 1.32 & 2.67 & $1.46^{*}$ & 54.7 \\
\hline SEM & 0.34 & & 0.32 & 0.65 & 0.34 & 0.5 \\
\hline
\end{tabular}

Agonists were used at $3 \mu \mathrm{M}$ concentrations except for dynorphin A ( $1 \mu \mathrm{M}$ for cells 4 and 5) and U69,593 (10 $\mu \mathrm{M}$ for cell 2).

* $p<0.01$ when compared in a $t$ test with respect to the algebraic sum of inhibitions produced by each drug alone. 
A
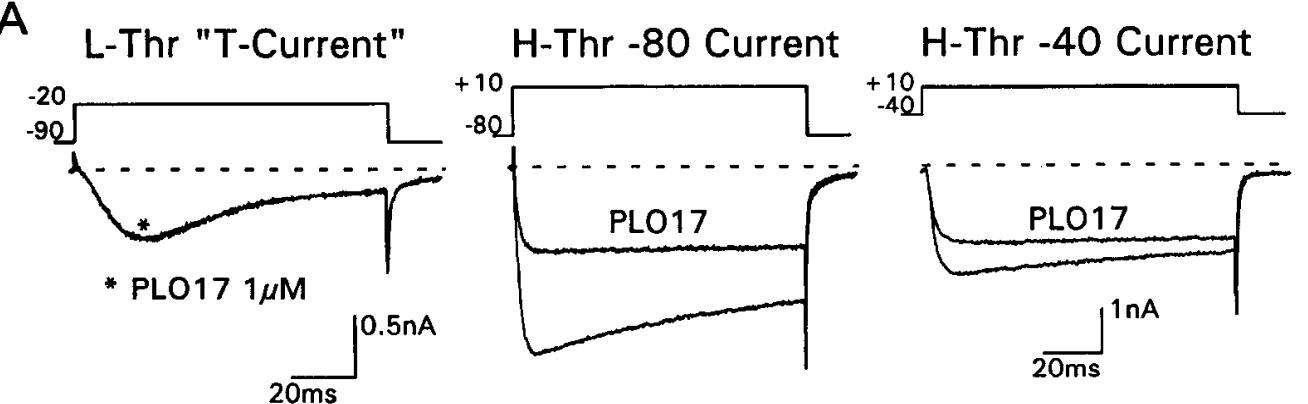

B
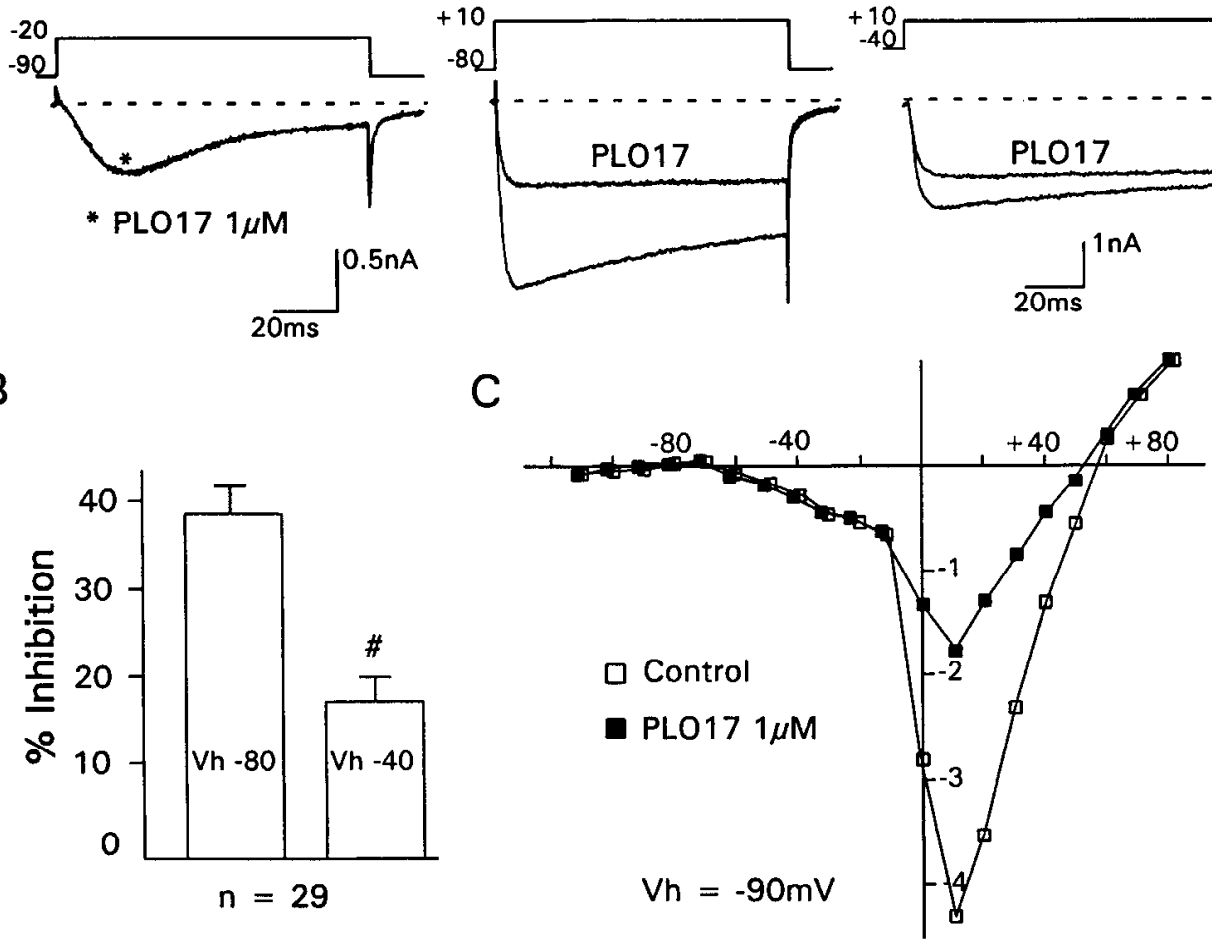

Figure 5. PLO17 selectively inhibited high-threshold calcium current. $A$, Voltage protocols used to separate low-threshold transient and highthreshold calcium current components are shown above pairs of the current records elicited in the absence and presence of PLO17 at $1 \mu \mathrm{M}$. All current records are from the same cell and were elicited by $100 \mathrm{msec}$ steps to the test potentials shown. Low-threshold T-type currents were isolated by steps to test potentials positive to $-60 \mathrm{mV}$ up to $-20 \mathrm{mV}$ from $V_{h}=-90 \mathrm{mV}$. The $\mu$-opioid agonist had no effect on low-threshold currents (traces at left), but reduced the peak and late current amplitudes of high-threshold currents evoked by commands to more positive test potentials $(+10 \mathrm{mV}$ ) after holding at $-80 \mathrm{mV}$ for $1 \mathrm{~min}$ (middle pair of traces). Holding at $-40 \mathrm{mV}$ for 1 min before stepping to $+10 \mathrm{mV}$ markedly reduced the peak current amplitude $\left(I_{p}\right)$ as well as the decay in current seen during the test pulse. This was associated with a corresponding reduction in the component of high-threshold current that was inhibited by PLO17 (traces at right). B, Bar graph compares the maximal inhibition by PLO17 of $I_{p}$ values in currents evoked by steps to $+10 \mathrm{mV}$ from $V_{h}=-80 \mathrm{mV}$ and $-40 \mathrm{mV}$ in each of 29 cells. The height of each bar is the mean percentage inhibition \pm SEM (error bars shown in one direction only), which was significantly different (\#, $p<0.01$ ) for currents evoked from $V_{h}$ $=-80 \mathrm{mV}$ and $-40 \mathrm{mV} . C$, Peak current-voltage plot derived from currents recorded in the absence (open squares) and presence of PLO17 $1 \mu \mathrm{M}$ (solid squares) for the cell shown in $A$. The plot was constructed by evoking a series of currents every 10 sec with hyperpolarizing and depolarizing voltage commands from $V_{h}=-90 \mathrm{mV}$ at test potentials ranging from $-110 \mathrm{mV}$ to $+80 \mathrm{mV}$ in $10 \mathrm{mV}$ increments.

-50 to $-20 \mathrm{mV}$ from $V_{h}=-90 \mathrm{mV}$. Among a sample of 47 neurons, $62 \%$ displayed the classic profile of T-type channel current, as illustrated by the neuron in Figure 5. In these neurons $(n=29)$, T-current consisted of a rapidly inactivating current whose maximal amplitude, obtained at test potentials of -25 to $-15 \mathrm{mV}$, was a small fraction (usually between $5 \%$ and $25 \%$ ) of the peak high-threshold current and gave rise to the characteristic shoulder in the current-voltage plot observed at the negative range of test potentials (Fig. $5 C$ ). Administration of PLO17 had no effect on T-current in any of these neurons (Fig. $5 A, C)$, despite the fact that high-threshold currents were reduced by the agonist in a majority of these cases $(n=22)$. T-currents were seen in six additional cells (12.8\%), but were unusual in being larger than the high-threshold current and reached their peak at more negative test potentials (also see Schroeder et al., 1990b; Scroggs and Fox, 1992). These giant T-currents were also unaffected by PLO17, as were the other calcium current components recorded in these cells. PLO17 reduced highthreshold current components in 9 of the 12 remaining neurons which had no $T$-current. It should be noted that $T$-currents were also unaffected by dynorphin $A$, but were reversibly reduced $10-20 \%$ by high concentrations of DPDPE $(10 \mu \mathrm{M})$ in a nal- oxone-resistant manner ( 4 of 4 neurons tested, naloxone at 1$10 \mu \mathrm{M})$.

We next sought to determine whether PLO17 might differentially affect kinetically distinct components of high-threshold current by using selective inactivation protocols to distinguish transient and sustained components of calcium current. In initial experiments, we evoked currents in many ( 29 of 31) of the opioid-responsive neurons studied above using $100 \mathrm{msec}$ steps to $+10 \mathrm{mV}$ at $1 \mathrm{~min}$ intervals after patch rupture, alternating between $V_{h}$ of -80 and $-40 \mathrm{mV}$. Clamping the neuron at -40 $\mathrm{mV}$ for prolonged periods prevented the activation of any T-type currents that were present and largely inactivated the highthreshold transient component(s), as evidenced by the fact that there was little difference between the mean values for $I_{p}(2.2$ $\pm 0.4 \mathrm{nA})$ and $I_{100}(1.9 \pm 0.3 \mathrm{nA}, p>0.5)$ of currents evoked from this reduced holding potential. In this way the sustained component could be examined in relative isolation and an estimate of transient high-threshold current(s) obtained from the additional more rapidly inactivating current component evoked at $V_{h}=-80 \mathrm{mV}$. Although PLO17 reduced currents evoked from both holding potentials, there was a clear voltage dependency to the reduction of high-threshold current by the opioid. 
As summarized by the bar graph in Figure $5 B$, administration of $3 \mu \mathrm{M}$ PLO1 7 had a significantly greater inhibitory effect on currents evoked from $V_{h}=-80 \mathrm{mV}(38.7 \pm 2.3 \%$,) than on those evoked from $V_{h}=-40 \mathrm{mV}(17.8 \pm 2.1 \%, p<0.01)$. The voltage dependence of this effect was also revealed by comparing the $I_{p}$ values of currents evoked from the two holding potentials; thus, differences in $I_{p}$ amplitudes observed in control recordings were largely eliminated in the presence of the agonist (compare middle and right traces, Fig. 5A). The reduction of high-threshold calcium current by PLO17 was found to be voltage dependent in another respect when current-voltage plots were used to assess the inhibitory action of the opioid on currents evoked over a larger range of test potentials. PLO17 reduced the peak inward current evoked at test potentials between -10 and +50 $\mathrm{mV}$, without producing an apparent shift in the voltage dependence of the current-voltage relationship (Fig. 5C). In comparison, outward currents, evoked at test potentials positive to +50 $\mathrm{mV}$, were unaffected by PLO17 (Fig. $5 C$ ) in all neurons examined $(n=28)$. These data are in keeping with conclusions reached in earlier reports that high-threshold transient current represents the principal component of calcium current that is inhibited by opioids (Gross and Macdonald, 1987; Gross et al., 1990a; Schroeder et al., 1991; Seward et al., 1991).

While the previous results suggested that the activation of $\mu$-opioid receptors preferentially inhibited high-threshold transient current, transient and sustained components were often insufficiently resolved in currents evoked by a $100 \mathrm{msec}$ test pulse to assess the selectively of this inhibitory effect. Therefore, in the remainder of our experiments we examined the effects of PLO17 on currents elicited with longer-duration commands (500-1000 insec), which yielded clearer separation of kinetically distinct high-threshold components. In addition, complete inactivation curves were generated to demonstrate more clearly any differential effect(s) of the $\mu$-opioid on current components arising from distinct populations of calcium channels. To separate current components by selective inactivation we applied prepulses of $3 \mathrm{sec}$ duration rather than holding the cell at various potentials to minimize possible confounding effects associated with current rundown. For these experiments, we also replaced calcium in the external bathing solution with barium $(2.0 \mathrm{~mm})$ as the charge carrier. This enabled us to record stable inward currents over relatively prolonged periods while avoiding potential confounding problems introduced by calcium-dependent inactivation.

The curves in Figure 6 were constructed by plotting the $I_{p}$ values of barium currents elicited by $1 \mathrm{sec}$ steps to $+10 \mathrm{mV}$ before, in the presence, and after washout of $3 \mu \mathrm{M}$ PLO17 as a function of the prepulse potential. In these cases, an abbreviated protocol was used with prepulse increments made in $30 \mathrm{mV}$ steps, rather than $10 \mathrm{mV}$ steps, so that control, drug, and wash trials could be performed on the same neuron. In control currents, the transient component was slightly inactivated by a prepulse to $-60 \mathrm{mV}$, showed half-maximal inactivation following a prepulse to $-30 \mathrm{mV}$ and was absent after a prepulse to 0 $\mathrm{mV}$. In the neuron shown in Figure $6 A$, PLO1 7 reduced $I_{p}$ values of currents elicited following prepulses from between -90 and $-20 \mathrm{mV}$, but was without effect on the $I_{p}$ values of currents evoked following more positive prepulse potentials. Results such as these (three of seven neurons tested) suggest that only the transient component of high-threshold current was inhibited by the $\mu$-opioid. In contrast, Figure $6 B$ illustrates a neuron (four total) in which inhibition of peak current amplitudes by PLO17 was observed following prepulses over the entire range of potentials from -90 to $+30 \mathrm{mV}$. Similarly, in a related series of experiments, PLO17 continued to suppress a fraction of highthreshold current elicited by a $1 \mathrm{sec}$ test pulse to $+10 \mathrm{mV}$ from $V_{h}=-80 \mathrm{mV}$ following prepulses to $-20 \mathrm{mV}$ which preferentially eliminated most of the rapidly inactivating component of current ( 7 of 11 neurons tested). Thus, we were unable to identify a single kinetically defined component of high-threshold calcium current that was selectively inhibited by $\mu$-opioid receptor activation. Moreover, findings like those shown in Figure $7 B$ suggest that $\mu$-opioid receptors might be negatively coupled to more than one type of calcium channel that contributes rapidly inactivating components of high-threshold current.

\section{PLO17 inhibits currents with different pharmacological sensitivities}

In a final series of experiments, we compared the effects of PLO17 on calcium currents evoked before and after administration of the reversible L-type calcium channel blocker nifedipine (Fox et al., 1987a,b; Regan et al., 1991) and $\omega$-CgTx, an irreversible and selective blocker of neuronal $\mathrm{N}$-type channels (McCleskey et al., 1987; Aosaki and Kasai, 1989; Plummer et al., 1989), to determine whether the channel(s) that contributes $\mu$-opioid-sensitive components of high-threshold current could be pharmacologically defined. In all cases, drugs were delivered by superfusion and calcium channel blockers administered at $10 \mu \mathrm{M}$, which was a saturating concentration in that the administration of a higher concentration of either agent, by itself, resulted in no additional reduction in control currents (data not shown).

The traces in Figure $7 A$ illustrate the inhibitory effect of 30 sec applications of PLO17 $(1 \mu \mathrm{M})$ on calcium currents evoked by $500 \mathrm{msec}$ steps to $0 \mathrm{mV}$ from $V_{n}=-80 \mathrm{mV}$ at the times and under the conditions indicated in the current versus time graph depicted in Figure $7 B$. On initial application, PLO17 reversibly reduced the $I_{p}$ amplitude by $62 \%$ from $2.9 \mathrm{nA}$ to 1.1 $\mathrm{nA}$ and eliminated most of the rapidly inactivating component of current (current declined only $27 \%$ from its peak amplitude by the end of the $500 \mathrm{msec}$ step, compared to $62 \%$ in control). Within $1 \mathrm{~min}$ after washout of the $\mu$-opioid, currents had recovered and $I_{p}$ values now showed a slight runup to $3.0 \mathrm{nA}$, at which point $\omega$-CgTx $10 \mu \mathrm{M}$ was applied. Administration of $\omega$-CgTx for $20 \mathrm{sec}$ irreversibly blocked $53 \%$ of the whole-cell current (reducing $I_{p}$ from 3.0 to $1.4 \mathrm{nA}$ ) and reduced the suppression in current produced by a subsequent application of PLO17 ( $I_{p}$ now inhibited by $\left.0.6 \mathrm{nA}\right)$. Thus, PLO17 must have inhibited the $\omega$-CgTx-sensitive current. Supporting this conclusion was the additional finding that in 6 of the 11 neurons in which $\omega-\mathrm{CgTx}$ was the sole antagonist tested, inhibitory responses to PLO17 were irreversibly lost following the block of transient high-threshold current by the toxin. Among these 11 neurons, the mean inhibitory response to PLO17 $(1-3 \mu \mathrm{M})$ was reduced from a $35.9 \pm 3.6 \%$ suppression in control current amplitude before $\omega$-CgTx to $20.1 \pm 4.7 \%(p<0.05$, paired $t$ test) inhibition in the peak current measured after $\omega$-CgTx.

The results from the neuron in Figure 7 illustrate the additional point that after the establishment of an irreversible block of transient calcium current by a saturating concentration of $\omega-\mathrm{CgTx}$, reapplication of PLO17 continued to exert a small inhibitory effect. This result, which was repeated in 10 additional neurons, strongly suggested that $\mu$-opioid receptors inhibit a second component of high-threshold current that is $\omega-\mathrm{CgTx}$ 

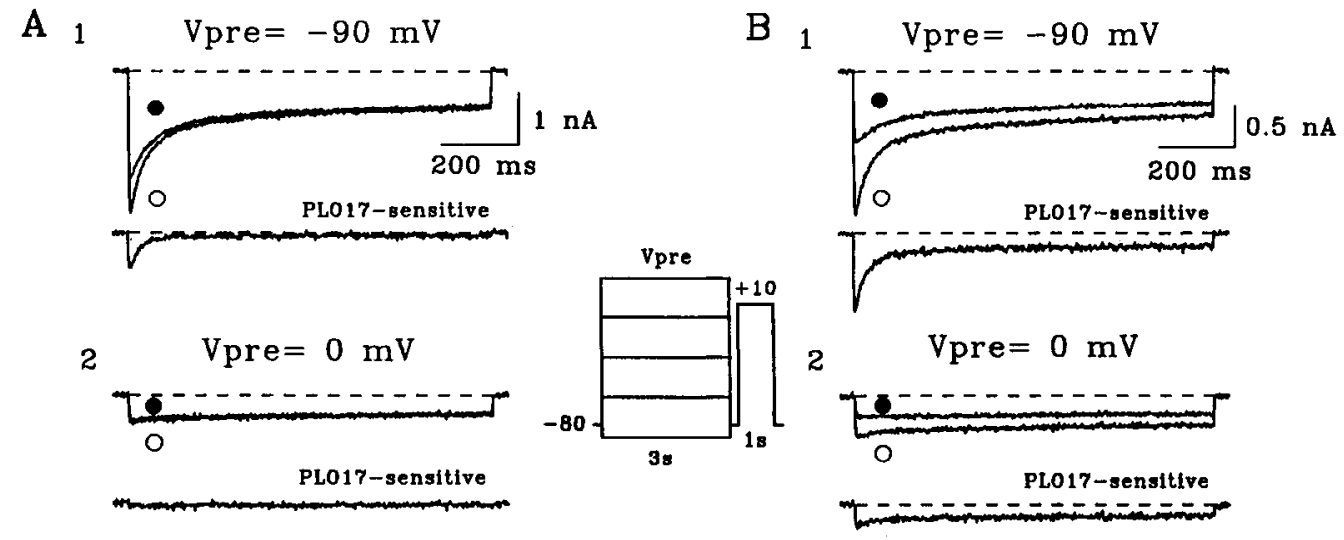

C

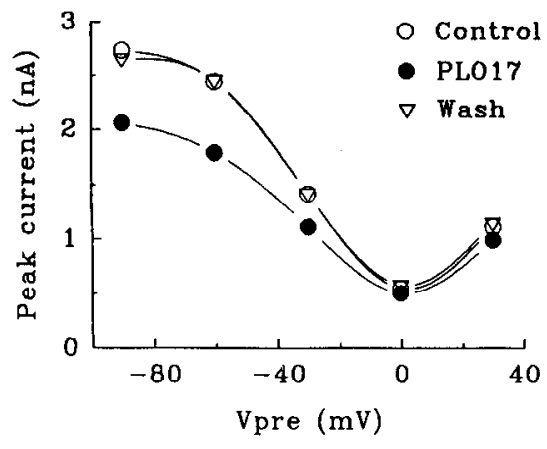

D

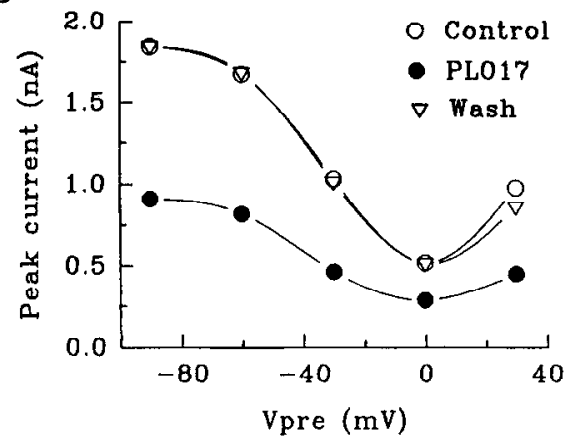

Figure 6. PLO17 reduced a transient high-threshold current that was resistant to inactivation by depolarized holding potentials. $A$ and $B$, Wholecell recordings (traces) from two DRG neurons show the inhibitory effects of PLO17 $1 \mu \mathrm{M}$ on barium currents elicited by 1-sec-duration steps to $+10 \mathrm{mV}$ following 3-sec-duration prepulses to $-90 \mathrm{mV}(A 1, B 1)$ or $0 \mathrm{mV}(A 2, B 2)$. Traces shown in $A$ and $B$ are from different neurons and were obtained during generation of complete inactivation curves depicted in $C$ and $D$, respectively. In these experiments, barium currents were evoked by $1 \mathrm{sec}$ steps to $+10 \mathrm{mV}$ following a $3 \mathrm{sec}$ prepulse to potentials of $+30 \mathrm{mV}$ to $-90 \mathrm{mV}$ (applied in that order) in increments of $30 \mathrm{mV}$ (protocol illustrated in inset). Between each prepulse and test pulse, the neuron was returned to $-80 \mathrm{mV}$ for $30 \mathrm{msec}$, which is too brief a time for recovery from inactivation (see Schroeder et al., 1990a). The graphs in $C$ and $D$ show the peak current evoked during the test pulse versus prepulse potential before (open circles), during (solid circles) and after (open triangles) washout of PLO17 at $1 \mu \mathrm{M}$ for the different neurons. In the neuron shown in $A$, a prepulse to $0 \mathrm{mV}$ abolished the transient component of current $(A 2$, upper pair of traces $)$ and with it all current that was sensitive to inhibition by PLO17 (A2, lower traces). Subtraction of traces before and in the presence of drug yielded PLO17-sensitive current (e.g., lower records in $A 1$ and $A 2$ ). By contrast, although for the cell shown in $B$ ) transient current was similarly abolished by prepulses to $0 \mathrm{mV}(B 2, u p p e r$ pair of traces), a large component of slowly inactivating current still remained that was inhibited by the $\mu$-opioid (B2, lower traces).

insensitive. We reasoned that if this residual effect of the opioid were due to an inhibition of the sustained component of highthreshold current, then it might be prevented or at least reduced in the presence of nifedipine. As shown for the cell in Figure 7, administration of nifedipine $10 \mu \mathrm{M}$ slightly reduced $I_{p}$ (by 0.25 $\mathrm{nA}$ ) and steady state amplitudes of calcium currents that were elicited under a background of irreversible blockade stemming from a prior exposure to $\omega$-CgTx. However, even this high concentration of nifedipine left unblocked a significant fraction of slowly inactivating current that was insensitive to $\omega-\mathrm{CgTx}$. Moreover, PLO1 7 continued to exert an inhibitory effect on the residual component(s) of calcium current that was elicited in the presence of these two blockers. Overall, we found no evidence that administration of nifedipine in saturating concentrations resulted in an attenuation of calcium current inhibition by PLO17 in any of seven neurons examined in this manner. A similar outcome was also obtained when this protocol was carried out at less negative holding potentials $\left(V_{h}=-40 \mathrm{mV}\right.$, $n=3$ ), which are known to promote dihydropyridine block of L-type channels (Bean, 1984; Fox et al., 1987a; McCarthy and TanPiengco, 1992). Thus, it would appear that $\mu$-opioid receptors are negatively coupled to two types of high-threshold cur- rent in DRG neurons: one that is sensitive to $\omega$-CgTx and a second that is resistant to block by $\omega-\mathrm{CgTx}$ and dihydropyridines.

\section{Discussion}

The present results demonstrate that PLO17, a highly selective $\mu$-opioid agonist (Chang et al., 1983; Blanchard et al., 1987), inhibited calcium channel currents in DRG sensory neurons acutely isolated from juvenile and young adult rats. This result is consistent with and extends recent findings by Schroeder and colleagues (1991) that activation of $\mu$-opioid receptors by DAGO reduces calcium currents in adult rat DRG neurons in shortterm culture. The inhibitory effects of PLO17, like those of DAGO, appeared to be mediated via the activation of $\mu$-opioid receptors. Several lines of evidence support this conclusion. First, we were able to block or reverse the inhibition in calcium current produced by $1 \mu \mathrm{M}$ PLO1 7 using naloxone in a nanomolar range of concentrations (1-10 nM) that corresponded well with the reported equilibrium dissociation constant of this antagonist at $\mu$-opioid receptors (see Williams and North, 1984; North, 1986). Second, PLO17 inhibited calcium currents in neurons that did not respond to administration of the $\kappa$-opioid-selective 
agonists dynorphin A or U69,593, and it was without effect in other neurons that showed a reduction in current by $\kappa$-opioids. Moreover, in neurons that responded to $\mu$ - and $\kappa$-opioid receptor agonists, administration of the $\kappa$-selective antagonist nor-BNI blocked responses to U69,593 while sparing the inhibition in current produced by PLO17. Thus, PLO17 must be acting at a site distinct from $\kappa$-opioid receptors to reduce the current in at least some cells. Third, administration of $\beta$-FNA which is known to irreversibly block $\mu$-opioid receptors (Takemori et al., 1981) abolished responses to PLO17, whereas inhibitions in calcium current by $\kappa$-opioid agonists remained largely intact. Lastly, the $\delta$-opioid agonist DPDPE failed to inhibit high-threshold calcium current in any neuron, thus ruling out $\delta$-opioid receptors in the mediation of PLO17's effects. Although high concentrations of DPDPE slightly reduced $\mathrm{T}$-current, this effect was insensitive to blockade by naloxone and therefore not mediated by opioid receptors.

Administration of the $\kappa$-opioid peptide dynorphin A reduced calcium currents in many of the neurons, including a large percentage that showed responses to PLO17. We attributed these effects to the activation of $k$-opioid receptors, since inhibition of calcium current by the peptide was blocked in a selective manner by the $\kappa$-opioid antagonist nor-BNI and was mimicked by application of U69,593. Given the high selectivity of U69,593 and nor-BNI for the $\kappa_{1}$-subtype of opioid receptors (Nock et al., 1988; Zukin et al., 1988) and that the dynorphins exhibit much higher affinity for $\kappa_{1}$-opioid binding sites, compared to the $\kappa_{2}$ opioid binding sites in brain (Nock et al., 1990), it is likely that $\kappa_{1}$-type opioid receptors are negatively coupled to calcium channels in rat DRG neurons. The finding that dynorphin A was more potent than U69,593 in suppressing calcium current can be explained by its having 20 -fold higher affinity for the $\kappa_{1}$-type opioid receptor from rat brain (Meng et al., in press). Overall, dynorphin A also appeared to be somewhat more effective than U69,593 (e.g., compare graphs in Fig. 2B), but it is unclear whether this was due to a difference in intrinsic efficacy of the two compounds or simply reflected an increased likelihood of "crossover" to $\mu$-opioid receptors by the peptide, compared to the more $\kappa$-selective U69,593.

In neurons that responded to $\kappa$-opioids and PLO17, the inhibition in calcium current produced by one class of agonist was often maintained, while responses to the other agonist were blocked by administration of antagonists having appropriate selectivity for its receptor. This result, which was obtained when using either a $\mu$-opioid ( $\beta$-FNA) or $\kappa$-opioid (nor-BNI) receptorselective antagonist, indicated that calcium channels can be modulated by both $\mu$-and $\kappa$-opioid receptors on the same DRG sensory neuron. In all neurons that were sensitive to opioids, the effect of $\mu$-opioid receptor or $\kappa$-opioid receptor activation consisted of a reduction in calcium current, including those cases in which responses were obtained using low nanomolar concentrations (10 $\mathrm{nm}$ being the lowest effective concentration) of agonists. The inability here and in previous studies (Macdonald and Werz, 1986; Schroeder et al., 1991) to substantiate the finding of Crain and coworkers (Shen and Crain, 1989, 1990) that opioids in low concentrations $(1-10 \mathrm{nM})$ increase neuronal calcium conductance suggests to us that this latter effect may reflect a phenomenon that is uniquely expressed in fetal mouse DRG neurons in explant cultures.

Although PLO17 was generally found somewhat less potent than dynorphin $A$ in reducing calcium current, the two agonists were equally efficacious, producing equivalent maximal reduc-
A

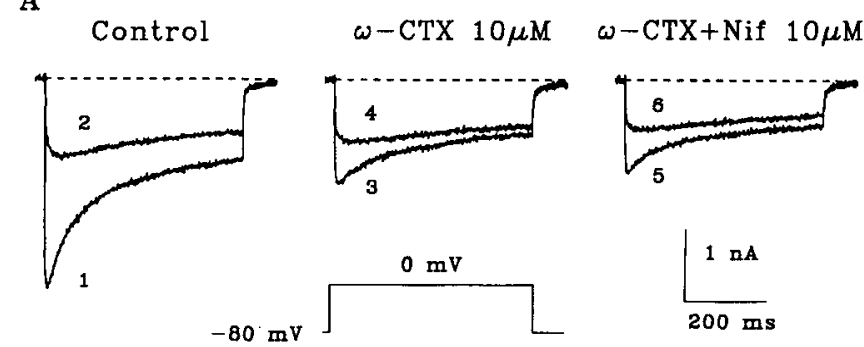

B

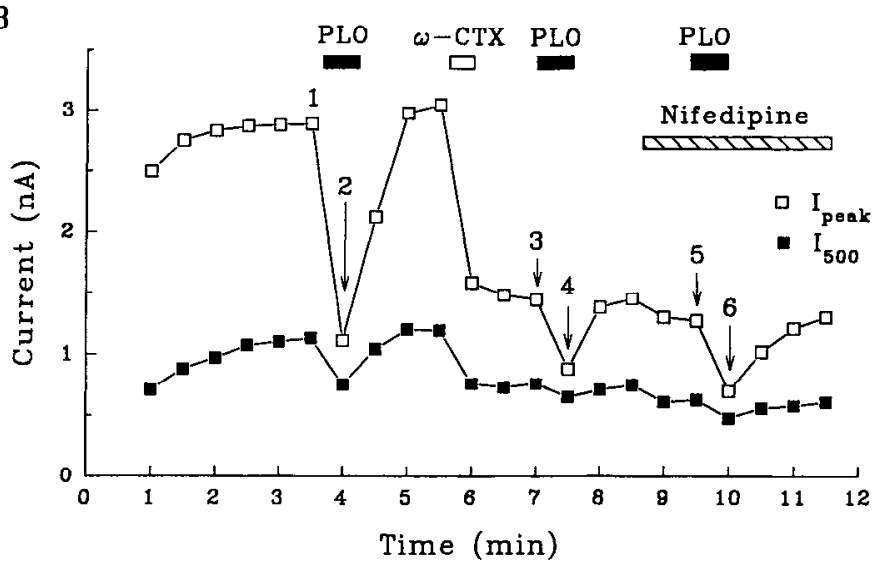

Figure 7. PLO17 inhibited $\omega$-CgTx-sensitive current and current that was resistant to both the toxin and nifedipine. $A$, Calcium currents (traces) elicited by $500 \mathrm{msec}$ steps to $0 \mathrm{mV}$ from $V_{h}=-80 \mathrm{mV}$ (voltage command protocol shown below current records) at the times indicated in the graph $(B)$ of current versus time after patch rupture. Administration of PLO17 $1 \mu \mathrm{M}$ for $30 \mathrm{sec}$ (indicated by solid bars in $B$ ) markedly reduced current amplitude ( $62 \%$ decrease in $I_{p}$ ) and eliminated a large fraction of rapidly inactivating current. Administration of $\omega$-CgTx in a saturating concentration $(10 \mu \mathrm{M}$, open bar in $B$ ) irreversibly suppressed the whole-cell current by $53 \%$ and this was associated with a reduced response to PLO17. However, PLO17 continued to inhibit a small fraction of the current that remained after the establishment of an irreversible blockade by the toxin (middle pair of traces). Moreover, the inhibitory effect of PLO17 was not diminished in the presence of a saturating concentration of nifedipine $(10 \mu \mathrm{M}$, hatched bar in B) (traces at right), which by itself reduced a small portion of the current that remained after exposure to $\omega-\mathrm{CgTx} . B$, Open and solid squares in the graph $(B)$ indicate peak current and amplitude of the late current, recorded at the end of the step, respectively.

tions in peak current when administered in saturating concentrations in a given neuron. In addition, the inhibitory effects of $\mu$ - and $\kappa$-opioids were found to be nonadditive. Thus, the inhibition of calcium current produced by PLO17 or dynorphin A alone was occluded when one of these agonists was applied in the presence of the other. These observations suggest that $\mu$ and $\kappa$-opioid receptors might be functionally coupled to a common population of calcium channels in DRG neurons. Because the dynorphins exhibit limited selectivity in their binding to $\alpha$ versus $\mu$-opioid receptors (Goldstein and Naidu, 1989), the possibility cannot be precluded that the observed nonadditivity might be in part a reflection of both PLO17 and dynorphin A acting as agonists on the same populations of opioid receptors. Yet, when the summation of responses to PLO17 and U69,593 (or dynorphin in some cases) was examined using saturating concentrations of these ligands to permit a clear expression of nonadditivity (see Deterre et al., 1982), the application of a maximal concentration of one agonist virtually eliminated the 
response to the other opioid. These results strengthen the argument for convergent modulation of calcium channels by $\mu$ and $\kappa$-opioid receptors, since the apparent affinity of U $U 69,593$ for $\kappa$-opioid receptors, like that exhibited for $\mu$-opioid receptors by PLO17, is nearly 4 orders of magnitude greater than that shown for other subtypes (Goldstein and Naidu, 1989). Moreover, they are compatible with the notion that $\mu$ - and $\kappa$-opioid receptors might inhibit calcium channel function via a common mechanism. Conceivably, this might occur through convergence in the intracellular transduction mechanisms to which they are coupled. Indirect evidence in support of such an hypothesis comes from recent demonstrations that a pertussis toxin-sensitive $G_{i}$ or $G_{o}$-type $G$-protein mediates the inhibitory coupling of $\mu$ - and $\kappa$-opioid receptors to $\mathrm{N}$-type calcium channels in $\mathrm{SH}$ SY5Y human neuroblastoma cells (Seward et al., 1991) and rat nodose ganglion neurons (Gross et al., 1990a), respectively. Recently, we have shown that a pertussis toxin-sensitive G-protein-linked mechanism is similarly involved in mediating the inhibitory effects of $\mu$-opioid receptor activation on calcium currents in rat DRG neurons (Moises et al., in press).

In the present experiments, PLO17 selectively reduced highthreshold components of calcium current, whereas low-threshold T-type currents were unaffected. The lack of an opioid effect on low-threshold current contrasts with recent findings by Schroeder et al. (1991) who found that the activation of $\mu$-opioid receptors inhibited $T$-type channel currents in adult rat DRG neurons in short-term culture. We doubt that our failure to demonstrate an effect of PLO17 on T-type channels could be attributed simply to sampling error, because this outcome was obtained among different subsets of DRG neurons exhibiting a heterogenous profile of low-threshold T-type currents (see also Schroeder et al., 1990b). This discrepancy in results between studies is also unlikely to be attributed to differences between freshly isolated and cultured cells, since we found that lowthreshold currents were also unaffected by the $\mu$-agonist in neurons that were maintained up to $6 \mathrm{~d}$ in culture. Moreover, we have shown previously that T-type currents were not reduced by dynorphin A in cultured mouse DRG neurons (Gross and Macdonald, 1987) and were similarly unaffected by $\kappa$ - and $\mu$-opioid agonists in acutely dissociated rat nodose ganglion neurons (Gross et al., 1990a). It is conceivable that the modulation of T-type channels by $\mu$-opioid receptors might reflect an age-dependent phenomenon that is expressed in adult sensory neurons, but absent in cells derived from juvenile rats (used here and in our studies on nodose neurons) or mouse embryos (Gross and Macdonald, 1987). As far as we know, no attempt has yet been made to address this issue in a systematic way. However, if this proves to be the case, the expression of this modulation of T-type calcium channels must appear after the first postnatal month, which was the cutoff date for the age of animals used in our experiments. Furthermore, the age-related nature of this change in coupling between opioid receptors and their targeted channels would suggest that $\mu$-opioid receptors are likely to influence different aspects of sensory neuron function during development and maturation compared to adult life.

Although transient and sustained components of high-threshold calcium current could be readily distinguished in whole-cell recordings from rat DRG neurons, the identity of the specific channel types that contribute to these different components remained unclear (Hess, 1990; Regan et al., 1991; Mintz et al., 1992a). Without attempting to resolve this issue, we were able to conclude that PLO17 selectively reduced current through calcium channcls that show rapid inactivation. This conclusion was based on the following observations. First, when variations in holding potential were used to separate kinetically distinct components of high-threshold current elicited by $100-500 \mathrm{msec}$ commands, administration of the opioid primarily affected the additional rapidly decaying current component evoked from $V_{h}$ $=-80 \mathrm{mV}$, compared to the sustained current evoked from $V_{h}$ $=-40 \mathrm{mV}$. Second, the kinetic effect of PLO17 was to eliminate the decay in current that occurred throughout the duration of voltage steps delivered from negative holding potentials. Our interpretation of these data is that the effect of the $\mu$-opioid agonist was to reduce a rapidly inactivating current component that was sensitive to depolarizing holding potentials, while sparing a sustained component of high-threshold current. However, an alternative explanation is that PLO 17 inhibited a single, highthreshold current component that was very sensitive to calciumdependent inactivation. In the latter case, a decrease in the amount of calcium influx by the opioid would have the combined effect of reducing macroscopic current amplitude and slowing the rate of current decay. We have rejected this possibility in favor of the first hypothesis, since the effect of PLO17 was the same whether calcium was used as the charge carrier or replaced by extracellular barium to minimize or prevent calcium-dependent inactivation (Eckert and Chad, 1984; Fox et al., 1987a).

Recent studies suggest that three types of calcium channels, commonly referred to by the designations of L-, N-, and P-type (for review, see Tsien et al., 1988; Hess, 1990) contribute highthreshold current in a variety of mammalian neurons, including rat DRG neurons (Regan et al., 1991; Mintz et al., 1992a). The properties of the transient current component that was inhibited by PLO17 suggest that the current may be contributed at least in part through $\mathrm{N}$-typc calcium channcls. Thus, $\mathrm{N}$-type channels have been shown to be sensitive to holding potential and exhibit more prominent inactivation during a maintained depolarization, than do L-type channels (Nowycky et al., 1985; Fox et al., $1987 \mathrm{~b}$ ), although the overlap in their inactivation kinetics appears to be more considerable that previously thought (Aosaki and Kasai, 1989; Plummer et al., 1989). The finding in a high percentage of neurons that reduction of calcium current by PLO17 was largely and irreversibly suppressed after administration of a saturating concentration of $\omega-\mathrm{CgTx}$ is also consistent with the notion that $\mathrm{N}$-type calcium channels are inhibited by $\mu$-opioid receptor activation. In keeping with conclusions reached in our earlier report (Gross and Macdonald, 1987), N-type channels in DRG neurons appear to be inhibited by $k$-opioid receptors, as well, since the loss of responses to PLO17 after toxin administration was associated with a concomitant suppression of inhibitory cffects clicited by dynorphin A.

Despite the arguments presented above, other data suggest that the profile of calcium current inhibition produced here by PLO17 cannot be readily attributed to the modulation of a single type of calcium channel. For example, in some neurons (as shown in Fig. 6B), administration of the opioid inhibited peak and steady state amplitudes of currents elicited following inactivation protocols that largely eliminated the transient component of high-threshold current. Recent demonstrations that the same $\mathrm{N}$-type channel can exhibit rapidly inactivating kinetics and sustained, noninactivating behavior (Plummer and Hess, 1991) could provide an explanation for the kind of experimental outcome depicted in Figure 6. However, in the single-channel recordings where this switching in inactivation ki- 
netics was seen, all N-type channel activity could he completely and irreversibly blocked by $\omega-\mathrm{CgTx}$ (Plummer and Hess, 1991; see also Aosaki and Kasai, 1989). By comparison, in approximately $40 \%$ of the neurons we examined with $\omega$-CgTx, PLO17 continued to reduce a sizeable fraction of the current that remained after establishment of an irreversible block of transient high-threshold current by a saturating concentration of the toxin. An inhibitory effect of $\mu$-opioids on $\omega$ - $\mathrm{CgTx}$-insensitive highthreshold current has also been found in short-term cultures of adult rat DRG neurons (Schroeder et al., 1991), although this was observed much less frequently than in the present study. We think it unlikely that the residual current that remained sensitive to PLO17 after $\omega$-CgTx was contributed by L-type channels, since inhibitory responses to the opioid were undiminished in the presence of a maximally effective concentration of nifedipine (10 $\mu \mathrm{M}$; see, e.g., McCarthy and TanPiengco, 1991). Moreover, the opioid continued to inhibit a component of current that was resistant to both blockers when we sought to promote the nifedipine block of L-type channels by eliciting currents from depolarized holding potentials (Bean, 1984; McCarthy and TanPiengco, 1992). In any event, we conclude that PLO17sensitive current is contributed primarily by a calcium channel that was blocked by $\omega-\mathrm{CgTx}$ and possibly by a second type of channel that was resistant to blockade by dihydropyridine blockers and $\omega$-CgTx.

At this point we can only speculate as to the identity of the channel(s) that contributes the residual fraction of $\omega$-CgTx-insensitive (non-N-type) and dihydropyridine-resistant (non-Ltype) current that was inhibited by PLO17. It is worthwhile to note that Bean and coworkers have provided evidence for a distinct type of high-threshold calcium channels in rat DRG neurons that are not blocked by $\omega$-CgTx or dihydropyridines (Regan et al., 1991; Mintz et al., 1992a). Interestingly, the corresponding component of high-threshold current found to be resistant to both types of blockers in their experiments resembled the residual fraction of PLO17-sensitive current described here, in that both high-threshold components exhibited inactivation kinetics similar to that shown by $\mathrm{CgTx}$-sensitive current, but were resistant to inactivation by depolarized holding potentials. Recent experiments involving use of the funnel web spider toxin, $\omega$-Aga-IVA, suggest that the dihydropyridine-resistant and $\omega$-CgTx-insensitive high-threshold current found in many rat central and peripheral neurons, including DRG neurons, is carried, at least in part, by channels similar to P-type channels described in Purkinje neurons (Mintz et al., 1992a). Hence, it will be of importance in future studies to determine the extent, if any, to which this spider toxin might affect the fraction of $\mu$-opioid-sensitive current that is insensitive to both $\mathrm{N}$-type and L-type calcium channel blockers. The finding that Aga-IVA blocks 70-80\% of depolarization-induced calcium entry into rat brain synaptosomes compared with an average of $30-40 \%$ of high-threshold current in cell bodies of central neurons has led to the suggestion that P-type channels might be preferentially concentrated in nerve terminals (Mintz et al., 1992b). Accordingly, the possibility that $\mu$-opioid receptors are negatively coupled to $P$-type calcium channels could provide a potentially significant mechanism by which opioids exert presynaptic inhibitory regulation of transmitter release.

\section{Note added in proof}

Since the submission of this article, Mintz and Bean (1993) have described the modulation of Aga-IVA-sensitive, high-threshold
P-type calcium channels in mammalian neurons by other pertussis toxin-sensitive G-protein-coupled inhibitory receptors. In recent experiments we found that Aga-IVA eliminated the PLO17-sensitive component of calcium current that persists after $\omega-\mathrm{CgTx}$ and nifedipine in a subset of DRG neurons, suggesting that $\mu$-opioid receptors are negatively coupled to P-type channels.

\section{References}

Aosaki T, Kasai H (1989) Characterization of two kinds of highvoltage-activated $\mathrm{Ca}$-channel currents in chick sensory neurons. Pfluegers Arch 414:150-156.

Attali B, Saya D, Nah S-Y, Vogel Z (1989) K-opiate agonists inhibit $\mathrm{Ca}^{2+}$ influx in rat spinal cord-dorsal root ganglion cocultures. J Biol Chem 264:347-353.

Bean BP (1984) Nitredipine block of cardiac calcium channels: high affinity binding to the inactivated state. Proc Natl Acad Sci USA 81: 6388-6392.

Bean BP (1989a) Neurotransmitter inhibition of neuronal calcium currents by changes in channel voltage dependence. Nature 340:153156.

Bean BP (1989b) Classes of calcium channels in vertebrate cells. Annu Rev Physiol 51:367-384.

Blanchard SG, Lee PHK, Pugh WW, Hong JS, Chang KJ (1987) Characterization of the binding of a morphine $(\mu)$ receptor-specific ligand: Tyr-Pro-NMePhe-D-Pro-NH ${ }_{2},\left[{ }^{3} \mathrm{H}\right]-\mathrm{PL} 17$. J Pharmacol Exp Ther 31: 326-333.

Carbone E, Lux HD (1984) A low voltage-activated, fully inactivating Ca channel in vertebrate sensory neurons. Nature 310:501-503.

Chang K-J, Wei ET, Killian A, Chang J-K (1983) Potent morphiceptin analogs: structure activity relationships and morphine-like activity. J Pharmacol Exp Ther 227:403-408

Chavkin C, James IF, Goldstein A (1982) Dynorphin is a specific endogenous ligand of the $\kappa$-opioid receptor. Science 215:413-415.

Deterre P, Paupardin-Tritsch D, Bockacrt J, Gerschenfeld HM (1982) cAMP-mediated decrease in $\mathrm{K}^{+}$conductance evoked by serotonin and dopamine in the same neuron: a biochemical and physiological single-cell study. Proc Natl Acad Sci USA 79:7934-7938.

Eckert R, Chad JE (1984) Inactivation of Ca channels. Prog Biophys Mol Biol 44:215-267.

Fox AP, Nowycky MC, Tsien RW (1987a) Kinetic and pharmacological properties distinguishing three types of calcium currents in chick sensory neurones. J Physiol (Lond) 394:149-172.

Fox AP, Nowycky MC, Tsien RW (1987b) Single channel recordings of three types of calcium channels in chick sensory neurones. J Physiol (Lond) 394:173-200.

Goldstein A, Naidu A (1989) Multiple opioid receptors: ligand selectivity profiles and binding site signatures. Mol Pharmacol 36:265272.

Gross RA, Macdonald RL (1987) Dynorphin A selectively reduces a large transient (N-type) calcium current of mouse dorsal root ganglion neurons in cell culture. Proc Natl Acad Sci USA 84:5469-5473.

Gross RA, Moises HC, Uhler MD, Macdonald RL (1990a) Dynorphin $A$ and CAMP-dependent protein kinase independently regulate neuronal calcium currents. Proc Natl Acad Sci USA 87:7025-7029.

Gross RA, Uhler MD, Macdonald RL (1990b) The cyclic AMP-dependent protein kinase catalytic subunit selectively enhances calcium currents in rat nodose neurones. J Physiol (Lond) 429:483-496.

Hamill OP, Marty A, Neher E, Sakmann B, Sigworth FJ (1981) Improved patch-clamp techniques for high-resolution current recording from cells and cell-free membrane patches. Pfluegers Arch 391:85100.

Hescheler J, Rosenthal W, Trautwein W, Schultz, G (1987) The GTPbinding protein, $G_{o}$, regulates neuronal calcium channels. Nature 325 : $445-447$.

Hess P (1990) Calcium channels in vertebrate cells. Annu Rev Neurosci 13:337-356.

James IF, Fischli W, Goldstein A (1984) Opioid receptor selectivity of dynorphin gene products. J Pharmacol Exp Ther 228:88-93.

Kasai H (1991) Tonic inhibition and rebound facilitation of a neuronal calcium channel by a GTP-binding protein. Proc Natl Acad Sci USA 88:8855-8859.

Lahti RA, Mickelson MM, McCall JM, Von Voigtlander PF 
[ $\left.{ }^{3} \mathrm{H}\right] \mathrm{U}-69593$ A highly selective ligand for the opioid $\kappa$-receptor. Eur J Pharmacol 109:281-284.

Loose MD, Kelly MJ (1990) Opioids act at $\mu$-receptors to hyperpolarize arcuate neurons via an inwardly rectifying potassium conductance. Brain Res 513:15-23.

Macdonald RL, Werz MA (1986) Dynorphin A decreases voltagedependent calcium conductance of mouse dorsal root ganglion neurones. J Physiol (Lond) 377:237-249.

McCarthy RT, TanPiengco PE (1992) Multiple types of high-threshold calcium channels in rabbit sensory neurons: high-affinity block of neuronal L-type by nimodipine. J Neurosci 12:2225-2234.

McCleskey EW, Fox AP, Feldman DH, Cruz LJ, Olivera BM, Tsien RW, Yoshikami D (1987) $\omega$-Conotoxin: direct and persistent blockade of specific types of calcium channels in neurons but not muscle. Proc Natl Acad Sci USA 84:4327-4331.

Meng F, Xie G-x, Thompson RC, Mansour A, Goldstein A, Watson SJ, Akil $H$ (in press) Cloning and pharmacological characterization of a rat kappa opioid receptor. Proc Natl Acad Sci USA, in press.

Mintz IM, Bean BP (1993) GABA $_{B}$ receptor inhibition of P-type $\mathrm{Ca}^{2+}$ channels in central neurons. Neuron 10:889-898.

Mintz IM, Adams ME, Bean BP (1992a) P-Type calcium channels in rat central and peripheral neurons. Neuron 9:85-95.

Mintz IM, Venema VJ,Swiderek K, Lee T, Bean BP, Adams ME (1992b)PType calcium channels blocked by the spider toxin $\omega$-AGA-IVA. Nature 355:827-829.

Moises HC, Rusin KA, Macdonald RL (in press) $\mu$-Opioid receptormediated reduction of neuronal calcium current occurs via a $G_{0}$-type GTP-binding protein. $J$ Neurosci, in press.

Mosberg HI, Hurst R, Hruby VJ, Gee K, Yamamura HI, Galligan JJ, Burks TF (1983) Bis-penicillamine enkephalins possess highly improved specificity toward $\delta$ receptors. Proc Natl Acad Sci USA 80: 5871-5874.

Murase K, Ryu PD, Randic M (1989) Excitatory and inhibitory amino acids and peptide-induced responses in acutely isolated rat dorsal horn neurons. Neurosci Lett 103:56-63.

Nock B, Rajpara A, O'Connor L, Cicero T (1988) [ $\left.{ }^{3} \mathrm{H}\right] \mathrm{U}-69,593$ labels a subtype of kappa opiate receptor with characteristics different from that labelled by $\left[{ }^{3} \mathrm{H}\right]$ ethylketocyclazocine. Life Sci $42: 2403-2412$.

Nock B, Giordano L, Cicero T, O'Connor L (1990) Affinity of drugs and peptides for U-69,593-sensitive and -insensitive kappa opiate binding sites: the U-69,593-insensitive site appears to be the beta endorphin-specific epsilon receptor. J Pharmacol Exp Ther 254:412419.

North RA (1986) Opioid receptor types and membrane ion channels. Trends Neurosci 9:114-117.

North RA, Williams JT (1985) On the potassium conductance increased by opioids in rat locus coeruleus neurones. J Physiol (Lond) 364:265-280.

North RA, Williams JT, Surprenant A, Christie MJ (1987) $\mu$ and $\delta$ receptors belong to a family of receptors that are coupled to potassium channels. Proc Natl Acad Sci USA 84:5487-5491.

Nowycky MA, Fox AP, Tsien RW (1985) Three types of neuronal calcium channels with different calcium agonist sensitivity. Nature 316:440-443.

Pepper CM, Henderson G (1980) Opiates and opioid peptides hyperpolarize locus coeruleus neurons in vitro. Science 209:396-396.

Plummer MR, Hess P (1991) Reversible uncoupling of inactivation in N-type calcium channels. Nature 351:657-659.

Plummer MR, Logothetis DE, Hess P (1989) Elementary properties and pharmacological sensitivities of calcium channels in mammalian peripheral neurons. Neuron 2:1453-1463.

Porthogese PS, I ipkowski AW, Takemori AE (1987) Binaltorphimine and nor-binaltorphimine, potent and selective $\kappa$-opioid receptor antagonists. Life Sci 40:1287-1292.

Regan LJ, Sah DWY, Bean BP (1991) $\mathrm{Ca}^{2+}$ channels in rat central and peripheral neurons: high-threshold current resistant to dihydropyridine blockers and omega-conotoxin. Neuron 6:269-280.

Sah DWY (1990) Neurotransmitter modulation of calcium current in rat spinal cord neurons. J Neurosci 10:136-141.

Schroeder JE, McCleskey EW (1993) Inhibition of $\mathrm{Ca}^{2+}$ currents in a defined subset of rat sensory neurons. J Neurosci 13:867-873.

Schroeder JE, Fischbach PS, Mamo M, McCleskey EW (1990a) Two components of high-threshold $\mathrm{Ca}^{2+}$ current inactivate by different mechanisms. Neuron 5:445-452.

Schroeder JE, Fischbach PS, McCleskey EW (1990b) T-Type calcium channels: heterogeneous expression in rat sensory neurons and selective modulation by phorbol esters. J Neurosci 10:947-951.

Schroeder JE, Fischbach PS, Zheng D, McCleskey EW (1991) Activation of $\mu$ opioid receptors inhibits transient high- and low-threshold $\mathrm{Ca}^{2+}$ currents, but spares a sustained current. Neuron 6:13-20.

Scroggs RS, Fox AP (1992) Calcium current variation between acutely isolated adult rat dorsal root ganglion neurons of different size. J Physiol (Lond) 445:639-658.

Seward E, Hammond C, Henderson, G (1991) $\mu$-Opioid-receptormediated inhibition of the N-type calcium-channel current. Proc R Soc Lond [Biol] 244:129-135.

Shen K-F, Crain SM (1989) Dual opioid modulation of the action potential duration of mouse dorsal root ganglion neurons in culture. Brain Res 491:227-242.

Shen K-F, Crain SM (1990) Cholera toxin-A subunit blocks opioid excitatory effects on sensory neuron action potentials indicating mediation by Gs-linked opioid receptors. Brain Res 525:225-231.

Surprenant AM, Shen KZ, North RA, Tatsumi H (1990) Inhibition of calcium currents by noradrenaline, somatostatin and opioids in guinea-pig submucosal neurones. J Physiol (Lond) 431:585-608.

Swandulla D, Armstrong CM (1988) Fast-deactivating calcium channels in chick sensory neurons. J Gen Physiol 92:197-218.

Takemori AE, Larson DL, Porthoghese PS (1981) The irreversible narcotic antagonistic and reversible agonistic properties of the fumaramate methyl ester derivative of naltrexone. Eur J Pharmacol 70: $445-451$.

Taussig R, Sanchez S, Rifo M, Gilman AG, Belardetti F (1992) Inhibition of the $\omega$-conotoxin-sensitive calcium current by distinct $G$ proteins. Neuron 8:799-809.

Tsien RW, Lipscombe D, Madison DV, Bley KR, Fox AP (1988) Multiple types of neuronal calcium channels and their selective modulation. Trends Neurosci 11:431-438.

Tsunoo A, Yoshii M, Narahashi T (1986) Block of calcium channels by enkephalin and somatostatin in neuroblastoma-glioma hybrid NG108-15 cells. Proc Natl Acad Sci LISA 83:9832-9836.

Werz MA, Macdonald RL (1983) Opioid peptides selective for muand $\delta$-opiate receptors reduce calcium-dependent action potential duration by increasing potassium conductance. Neurosci Lett 42:173178.

Williams JT, North RA (1984) Opiate-receptor interactions on single locus coeruleus neurones. Mol Pharmacol 26:489-497.

Wimpey TL, Chavkin C (1991) Opioids activate both an inward rectifier and a novel voltage-gated potassium conductance in the hippocampal formation. Neuron 6:281-289.

Zukin R, Eghbali M, Olive D, Unterwald E, Tempel A (1988) Characterization and visualization of rat and guinea pig $\kappa$ opioid receptors: evidence for $K_{1}$ and $\kappa_{2}$ opioid receptors. Proc Natl Acad Sci USA 85: 4061-4065. 